\title{
Rhetoric Analysis on the Relationship between Executive Compensation and Performance of Commercial public enterprises in Namibia.
}

\author{
Dr Helena Megameno Nailonga Ngalandji-Hakweenda \\ International University of Management \\ P.O. Box 86962, Eros \\ Windhoek
}

\begin{abstract}
The purpose of this paper was to investigate the relationship between compensation packages and the performance of executive officers in Commercial Public Enterprises in Namibia. The paper was conducted to achieve the following specific objective: to determine the relationship between compensation packages of executives and the performance of Commercial PEs in Namibia. It was all in the context of mixed research approach for data collection using a questionnaire as a tool. The study found that there is a partial relationship between executive compensation and the performance of some commercial public enterprises, in accordance with their Tier Levels. It is recommended that the Government (shareholder) finds the best fit model of executive compensation packages in order to induce a positive level of performance. It is further recommended that a study be conducted, to investigate the relationship between the role of an independent high-level committee on executive compensation packages, aimed at enhancing performance in Commercial Public Enterprises in Namibia
\end{abstract}

Keywords: Compensation Package; Performance; Commercial Public Enterprises; Executives

\section{Introduction}

Management should have the aptitude to run a company in the interests of the owners. However, management does not only think about the shareholders; managers also look for personal gain. Problems arise when the interests of the managers are different from the interests of the shareholders this is commonly referred to as the agency problem. Certainly, conflict will occur unless the compensation of management is somehow tied to the interests of shareholders. This makes the relationship between compensation packages, the executive and overall company performance an important area of study. However, much remains to be done in this area. What is known is that executives receive excessively high remuneration, which is often not linked to their individual performance or that of their companies.

A strong management is the backbone of any successful company. Though employees are also important, it is management that ultimately makes the strategic decisions which move companies forward (Investopedia, 2019). In this sense, management may be compared to the captain of a ship. While not physically sailing the boat, he or she directs others to look after all the factors that ensure a safe voyage. In principle, the management of a publicly traded company is in charge of creating value for shareholders. Management is to have the business acumen to run a company in the interests of the owners. However, management does not only think about the shareholders; managers also look for personal gain. Problems arise when the interests of the managers are different from the interests of the shareholders - the agency problem. The agency theory postulates that conflict will occur unless compensation of management is aligned with the interests of 
shareholders (Investopedia, 2019). Yet, the fact remains that the board of directors will always support the shareholders' side; and management must also add value to shareholders (Hayes, 2019).

Most investors realise that it is important for a company to have a good management team (Murphy, 2019). However, evaluating management is a difficult task since many aspects of their job are intangible. It is clear that investors cannot always be sure of the performance of a company by only tapping over financial statements. An important lesson from the fallout of United States companies, such as Enron, WorldCom and ImClone is the importance of emphasising the qualitative aspects of a company (Investopedia, 2019). There is no magic formula for evaluating management, but there are factors that should be given attention.

Reports and/or studies looking into the remuneration trends of executives in Namibia include the Deloitte \& Touche (2010) study and The Villager (2013) survey on why contracts of CEOs are terminated. A brief of these studies as reported in the local newspapers by Weidlich (2010) and Gaoes (2013) is as follows:

The report by Weidlich (2010) made reference to the Government Gazette (2010), the SOE Council, as mandated by the SOEs Act 2006, where the implementation of the Remuneration Framework for CEOs, Senior Managers and Board of Directors of SOEs with maximum caps on the amounts were presented. The framework approved by Cabinet divides SOEs into three categories: Tier 1, Tier 2 and Tier 3. It is further reported by Weidlich (2010) that the Deloitte \& Touche study (2010) arranged the 60 SOEs into three different categories according to revenue, number of employees, their skills and total assets. Hence tier three, being the highest, consisted of companies like Air Namibia, the Namibia Ports Authority, Namibia Power Corporation, Telecom Namibia, TransNamib Holdings Ltd, Roads Contractor Corporation, NamPost and Meat Corporation of Namibia. The second tier includes companies like Agricultural Bank of Namibia, Development Bank of Namibia (DBN), Namibia Airports Company (NAC), and Namibia Broadcasting Corporation (NBC) among others. The third tier includes companies like New Era Publication Company, Electricity Control Board, Meat Board of Namibia, Namibia Qualifications Authority (NQA), and Namibia Tourism Board (NTB) among others. In terms of this framework, a CEO in Tier 1 should only earn between $\mathrm{N} \$ 401199$ and N\$803 413 annually, while those in Tier 2 should earn between N\$451 739 and N\$987 197 annually, and the CEOs of Tier 3 SOEs, should earn minimum N\$709 722 and a maximum of N\$1 532828. Under this framework, the task of strategic directions and operations is placed in the hands of the respective Boards of Directors for the SOEs and their management. Hence, once the Board of Directors is appointed, the performance of the SOE is left entirely upon them. This has resulted in some SOEs performing well but unfortunately some not. However, at that time it was established on the ground that a significant number of SOEs, for reasons unknown to the Council, ignored the Council. In particular, regardless of the framework, several CEOs continued to earn above the stipulated caps (Shihepo 2014, Govt fails to rein in CEOs earning above salary cap, para. 5).

All the same, the job of Chief Executive Officer in Namibia's Public Enterprises is every graduate's dream. However, one of the highest paid positions in the country is also one of the least secure jobs, as executives end up fired, suspended, having to pay fraud-related fines or settlements and are often left with nothing but the prospect of never finding another job in the public sector. As revealed by Gaoes (2013, Disgraced CEOs: Where are they now, para.2) in citing the Deloitte and Touche Chartered Accountants, report on corporate governance (2013), this practice is disturbing and in contravention of good governance practices as stipulated by the Companies Act of 2004. Section 235 of the Act states a company must not make payments to any director as compensation for loss of office, unless full particulars have been disclosed and the payment has been approved by a special resolution of the company.

Initially, the report by Gaoes (2013) expresses concern over the fact that a number of parastatal CEOs who resigned from their jobs in Namibia in recent years have been offered compensation perks by the boards in the absence of formal performance evaluations and performance management processes that should have 
been instituted before the suspensions. Another thorny issue, according to Gaoes (2013)'s report, is the proliferation of SOEs, which has seen their number increase from 42 in 2009 to 72 by 2013 . Hence, the report suggested: "This proliferation of new SOEs and the number of SOEs should be reviewed against the key criteria of whether they are providing essential services and products, which the private sector cannot or is not providing" Gaoes (2013).

Of equal concern were the procedures that are employed in the hiring of Managing Directors at local SOEs or the lack thereof. Worse still, seemingly unqualified members of Boards of Directors at the SOEs suspend or fire Managing Directors with no regard of the prevalent labour laws. This has resulted in financial losses for these companies when they had to pay compensation or give golden handshakes to inappropriately dismissed executives.

A more accurate explanation as to why CEOs get fired as reported by Gaoes (2013, Disgraced CEOs: where are they now, para.6) is that the Boards of Directors or shareholders lose confidence in their ability to generate sufficient financial returns in the future. In most cases, the Boards personalise their differences with CEOs (Gaoes, 2013). In a nutshell, the Villager newspaper study (2013) conducted on CEO terminations traced some of the executives who unceremoniously left their jobs and although it is a commonly held belief that CEOs get fired or are forced to resign or retire under pressure because of non-performance, many in Namibia lose their jobs due to a breakdown in internal relations (Gaoes, 2013)

It is against the above background that, a strong remark was made by the Former Prime Minister, Nahas Angula, upon relinquishing his premiership role, where he re-emphasised that one of Geingob's challenges (his successor by then) would be dealing with the SOEs, including massive salary discrepancies and enterprises that continue to operate in the red (Immanuel 2013, Geingob changes SOE categories, para.22).

In relation to the above, immediately upon resuming the premiership, the Prime Minister Hage Geingob released a government gazette amending the State-Owned Enterprises Governance Act of 2006 where a number of SOEs were removed from the SOE tiers to an unclassified category (Immanuel, 2013). The affected SOEs included the Polytechnic of Namibia, the Government Institutions Pension Fund (GIPF), the Namibian Broadcasting Corporation (NBC) and the University of Namibia. This meant the unclassified SOEs were no longer subject to salary ceilings for those heading the Organisations.

The above SOEs' performance controversy continues to prevail as reported by the Windhoek Observer (2 June, 2016, p.2) that, the slashing of parastatal funding, which was being led by the Finance Ministry, had already seen over $\mathrm{N} \$ 81,7$ million being chopped off SOE operational budgets, which initially stood at over N\$961 million. According to the Windhoek Observer (2016), the government had been funding inefficiencies and that needed to change going forward. In addition, the Windhoek Observer (2016) reported that, top managers at some SOEs are reported to be drawing huge salaries, despite running non-performing entities.

On how the SOEs will survive, considering their dependence on Government bailouts annually, the Finance Minister, as noted in the Windhoek Observer (2016), proposed reforms that would be implemented by the Public Enterprises Ministry, led by Leon Jooste, who should provide some guidance: "There are reforms that are being introduced by the Ministry of Public Enterprises and those should allow them to become selfsustainable, reducing our part in funding them" said Schelettwein (Windhoek Observer, 2016, Honeymoon over for SOEs, para.4 ).

Contrary to the above, is the report by Immanuel and Ngutjinazo (2018,Honeymoon over for SOEs,para.1) who revealed that government had approved new rules that increased salaries of Public Enterprise bosses and senior managers, with the highest rated Chief Executives qualified to earn over N\$2 million a year excluding bonuses. These details were revealed in the Government Gazette published on 16 May, 2018 by Public enterprises Minister Leon Jooste. This has been noted to be the latest new regulations regarding 
remuneration review since the last pay regulations on SOE management by Prime Minister Hage Geingob in 2013.

In Namibia a glance at the salaries of top executives of public enterprises quickly leads to the conclusion that MDs of parastatals are over-paid as per the citizens' outcry (The Patriot, 2017). Naturally, the executives defend themselves by arguing that they are actually underpaid by one or the other criterion (The Patriot, 2017). Given the above debate, Commercial Public Enterprises are well known for being bailed out by the Government year after year (Ngatjiheue, 2018, Govt spent $\mathrm{N} \$ 12 \mathrm{~b}$ on SOEs last year, para.1). As revealed by Ngatjiheue (2018) the Namibian Government spent more than $\mathrm{N} \$ 12$ billion in sustaining the public enterprises in 2017/18 alone. The government paid commercial SOEs a subsidy of $\mathrm{N} \$ 868$ million and gave a government guarantee of $\mathrm{N} \$ 4,9$ billion, while financial SOEs received subsidies of $\mathrm{N} \$ 60$ million and guarantees of $\mathrm{N} \$ 3,6$ billion, whereas non-commercial SOEs received $\mathrm{N} \$ 2,5$ billion worth of subsidies and a government guarantee of $\mathrm{N} \$ 322,5$ million.

However, the above investment has not yielded tangible returns according to Jooste, the Minister of PEs (2018) (as cited in Ngatjiheue, 2018) who explained that, during the 2017/18 financial years PEs made losses of more than $\mathrm{N} \$ 150$ million. Even though in 2016 the total value of PE assets stood at $\mathrm{N} \$ 91$ billion, by the end of 2017 PEs debt was N\$43 billion, about 25\% of GDP. Sixty-seven percent (67\%) of the N\$43 billion was owed by commercial state-owned enterprises (SOEs), while non-commercial entities owed 17\% and financial institutions $16 \%$. Other pertinent information revealed by Public enterprises Minister Leon Jooste was that out of the allocated budget of N\$12 billion for PEs in the 2017/18 financial year, N\$6, 1 billion was earmarked for the wage bill which was not sustainable at the present level of performance and financial results coming from SOEs.

The performance of Commercial PEs, as summarised in the statistics above, would suggest that there might be a mismatch between the earnings of executives and the actual performance of the Public Enterprises in Namibia. Therefore, the problem identified is that little or no effort is made at investigating the impact of pay packages of top executives of public enterprises on either the performance of the executives or that of the organisations. Many Public Enterprises do not disclose the processes for determining the compensation packages of their executives, nor do they reveal what they actually paid.

The government of Namibia has since 2006 instituted reforms in the operations of SOEs, "including a review of the salary structure" (Amupadhi, 2008). No doubt a lot of emphasis was put on salary levels, considering remarks made by politicians in and outside parliament. A couple of years ago, the Prime Minister's Office reportedly issued an order that all state-owned companies pay salaries equivalent to those in the public service. A CEO would be on the level of a Permanent Secretary. The move was ill-considered by all SOEs and hence, the Premier's order died quietly (Amupadhi, 2008).

Further reforms that have been made to improve the performances of SOEs included putting them into categories and putting seals on the salaries of their MDs/CEOs. Also, the Prime Minister removed some institutions from the list (Immanuel 2013). This observation raises a number of questions that must be answered for remuneration of executives of SOEs to reflect the performance of the organisations:

- How do the packages of top executives of commercial public enterprises correlate with the performance of these executives as measured by the performances of the Organisations they lead?

- What process is followed in determining the packages of top executives in commercial public enterprises?

- What effect have the reforms of PEs, "including a review of the salary structure", instituted by the government of Namibia had on the operations and performance of SOEs?

- To what extent had the order from the Office of the Prime Minister that all SOEs pay salaries equivalent to those in the public service, which would make a CEO of an SOE be on a salary at the same level as a Permanent Secretary been effected? 
The Minister's observation that the $\mathrm{N} \$ 6,1$ billion wage bill of PEs is not sustainable at present levels of performance and financial results requires that these questions be addressed. Hence, this study will explore some of the issues in these questions. The Windhoek Observer (2016) revealed that the top managers of some SOEs are reported to be drawing huge salaries while running non-performing entities. Supporting this, Immanuel and Ngutjinazo (2018) argued that even though regulations in 2014 stated that CEOs in Tier Three should not earn more than $\mathrm{N} \$ 1,6$ million, some of them were paid well above that. For instance, NamPower's Managing Director, Simson Haulofu, was offered N\$3, 4 million a year in 2016, which was above the stipulated rate.

The purpose of this paper was to investigate the relationship between compensation packages and the performance of executive officers in commercial Public Enterprises in Namibia. This study was conducted to achieve the following specific objective:

$>$ To determine the relationship between the compensation package of executives and the performance of Commercial PEs in Namibia.

\subsection{Significance of the Study}

The paper contributes to the body of knowledge as it addresses an issue of concern to both academics and political leaders - the lack of performance and high compensation of CEOs/MDs of Commercial Public Enterprises in Namibia. Further, the paper identified areas for further research like the importance of organisational equilibrium, ineffectiveness and uneconomical expenditure as performance measures in PEs.

This paper may contribute to positive socio-economic change by raising individuals' awareness of the impact that compensation packages have on executive performances and that of the organisation when suitable theoretical frameworks such as organisational equilibrium and agency theories are followed. Additionally, compensation committees of the public enterprises can use the findings from this study to evaluate their compensation strategies and make necessary adjustments.

Equally, the perception of how compensation packages impact on the executive performance within Commercialised Public Enterprises may be used by the organisations and HR practitioners to direct and inform strategies for organisational effectiveness and business excellence.

\subsection{Theoretical Framework}

The paper to assess the impact of compensation packages on the performance of executives in Public Enterprises in Namibia is combined with the scholarship in these studies in a way that contributes to the body of knowledge. Onuorah (2019) takes a slightly different angle; he explains that employees' willingness to stay on the job largely depends on compensation packages of the organisation. In an attempt to ensure employees' optimal performance and retention, organisations need to consider a variety of appropriate ways to reward the employees to get the desired results (Falola, Ibidunni and Olokundun, 2014; as cited in Onuorah, 2019).

A study by Onuorah, Okeke, and Ikechukwu (2019) was anchored on the Human Capital Theory and the Expectancy Theory. It has been argued that the degree to which employees are satisfied with their job and their readiness to remain in an organisation is a function of the compensation packages and reward systems of the organisation (Fadugba, 2012). Yet, these studies were broadly targeting all employees' performance including Executives in relation to their compensation in Nigeria. A similar hypothesis of the current study was restricted to executive compensation and performances in Namibia's commercial public enterprises. Taking the above into consideration, this study adopted the organisational equilibrium and agency theories as the main guiding theories.

As clearly explained in Bussin (2018), executive compensation is vital in attracting, motivating and retaining the most senior employees of an organisation, and its efficiency and effectiveness are measured by sustained organisational success at the least economic cost to shareholders (Bussin 2012; Faulkender et al., 2010; Shaw \& Zhang 2010). 
Deloitte (2017) also highlighted that it is not just the cost of executive compensation that has garnered attention in the literature and the media, but it is the cost of executive compensation relative to the cost of lower paid employees that has become an issue of societal concern worldwide. Desirable compensation packages are created to ensure the ability of the organisation to attract and retain the best possible CEOs. The most common determinants for executive compensation are organisation size; organisation performance; executive-specific factors; organisation structure; job or position-specific factors; and job complexity (Bussin, 2012). So, executive compensation should not be divorced from "organisational performance" - when organisational performance is low, it reflects performance of the executive, and that should influence compensation. However, this is not happening in Namibia; Ngatjiheue (2018) has argued that the $\mathrm{N} \$ 6,1$ billion wage bill is neither sustainable at the present level of performance and financial results of SOEs nor is it market-related. For example, on compliance ratings, Ngatjiheue (2018) demonstrated that of all SOEs in Namibia, only $27 \%$ had compliance ratings for audited financials, $20 \%$ for governance agreement, $25 \%$ for performance agreement and $48 \%$ for business plans.

Kuepper (2019) highlighted that executive compensation is a significant thing to consider when evaluating an investment opportunity. Executives who are improperly compensated may not have the incentive to perform in the best interests of shareholders, which can be costly for those shareholders. However, this also means that when executives are not performing well, they should not continue to draw huge compensation. While new laws and regulations have made executive compensation much clearer in company filings in the USA, many investors in the USA remain clueless as to how to find and read these critical reports. It is therefore necessary to provide information on the different types of executive compensation and how investors can find and evaluate compensation information, which makes the summary below useful.

\subsection{Understanding compensation packages of executives in Public Enterprises}

Although many studies have been conducted for over four decades, there is still no conclusive evidence on the relationship between remuneration of executive directors and the financial performance of their organisations, with many studies producing conflicting results (Bruce, Buck \& Main, 2005; Bussin \& Blair, 2015; Kirsten, 2018). Kirsten (2018)'s study was an investigation of conclusions reached in previous studies conducted in South Africa that companies within the consumer goods and services industry do not seem to base executive director remuneration on the accounting performance of the company, but rather on their market performance. Other studies that have reached similar conclusions include Cosh (1975), Hirschey and Pappas (1981), Lewellen and Huntsman (1970), Masson (1971) and Meeks and Whittington (1975). All of these studies used accounting information to measure the profitability of companies; and the measurement errors inherent in such information produced biased empirical results (Coughlan \& Schmidt 1985).

The scope of Kirsten (2018)'s study was on companies listed on the Johannesburg Stock Exchange (JSE) in South Africa. A quantitative research method was used to analyse the relationship between performancebased payments and the overall performance of companies. In particular, a sample of 42 listed South African companies from the consumer goods and services industry were used. This meant that to attain more conclusive results, future researchers should study a wider range of industries as well as companies not listed on the JSE or listed on other platforms. The performance measures used to conduct the research were also limited to more traditional performance measures which can be calculated using traditional cost management systems and figures found in financial statements. These traditional performance measures such as financial based measeres have various limitations which compromise their relevance in the current competitive markets (Ghalayini \& Noble, 1996). A wide assortment of performance measures is available which includes non-financial performance measures (Kirsten, 2018). Hence, the research opportunity tapped on assessing the impact of Compensation Packages on the Performance of Executives in commercial Public Enterprises. It was conducted using more modern performance measurement systems such as economic output.

According to Arif (2019), employee performance is the quality and quantity of the work outcome achieved by an employee and it reflects how well the employee meets the requirements set by the goals of an 
organisation. The results of Arif (2019)'s study are in agreement with those of Mayanti (2007, p.167) that, performance also means work performance, work implementation, work achievement or work outcome/performance. Thus, it is said that performance is the result or output of a process. Another study that agrees with this conclusion is Prawirosentono (2008: p.236), as cited in Arif (2019), and it identifies at least 10 factors that affect employees' performance:

1. The employees' knowledge regarding the work that becomes their responsibility.

2. Technical knowledge regarding the work that becomes the responsibility of an employee must be assessed since it is related to the employee's work quality and speed in completing the job that becomes their responsibility.

3. The employee's dependence on other people needs to be assessed since it relates to one's self confidence in carrying out one's work.

4. The employees' instinctive judgment. This is an important factor which helps to find out whether the employees have the ability to adjust and assess their duties in order to support the organisational goals.

5. The employees' ability to communicate (communication skill) with the fellow employees.

6. The employees' ability to work with the other employees.

7. The employees' attendance at meetings along with the ability to convey their ideas to the others has its own value in assessing their performance.

8. The employees' ability to manage the works that become their responsibility, such as creating their work schedules generally will affect the employees' performance.

9. Leadership is one of the factors that have to be assessed in determining the employees' work performance, especially for employees who have talent for leading, mobilising and motivating their colleague to work better.

10. The employees' desire to improve their ability also becomes one of the factors to assess the employees' performance. Hence, a need to undertake a research study to determine the magnitude to which compensation packages influences the performances of executives in Commercial Public Enterprises.

Mari (2018)'s study also predicted the factors that influence performance to include organisational culture, compensation and commitment. The study used purposive sampling technique with 107 employees as respondents. The study only covered bank employees. Thus, caution should be applied not to generalise the results of that study to other samples and contexts. Accordingly, Mari's study advised that in order to gauge the perspective of the impact of job satisfaction and influencing factors on employee performances, it would be correct to consider a cross-sectional research in a variety of geographical set ups. The results of Mari's study indicate simultaneously how organisational culture, compensation, and commitment affect performance: partially, organisational culture influences performance, organisational culture influences commitment and compensation influences commitment. However, compensation does not affect performance.

Mari (2018) cited other studies that have also concluded that organisational culture and compensation simultaneously have a significant influence on performance: Yamali (2018), Sajangbati (2016), Lukman and Adolphina (2012). Though Yamali (2018) used a small sample, his study concluded that compensation and organisational culture affects performance. Sajangbati (2016)'s study also showed that the trio that influenced performance was compensation, career development and motivation. Lukman and Adolphina (2015)'s study also showed that in addition to compensation, other factors that influenced performance were the work environment and commitment - with organisational commitment possibly being the most dominant variable. Since, the purpose of their study was to determine the effects of the work environment, organisational commitment and compensation on the performance of employees of PT Bank of North 
Sulawesi Manado, one can conclude that there is a geographical limitation in terms of the study population at societal and organisational level. Lukman and Adolphina's study adopted a quantitative research method with a population of 211 people and used Slovene's formula to obtain a sample size of 68 respondents; and multiple linear regressions was used for data analysis.

On the other hand, Bognanno (2010)'s article on executive compensation explained that the compensation of CEOs is generally viewed within an agency framework (The gist of the agency theory is found in the Bible, John 10:12: 'He who is a hired hand, and not a shepherd, who is not the owner of the sheep, sees the wolf coming, and leaves the sheep and flees, and the wolf snatches them and scatters them'). The separation that exists between the owners and managers in corporations gives rise to an agency problem in which managers have an incentive to pursue their personal interests over the interests of shareholders. The increase in the components of pay that are linked to firm performance, stock option schemes for example, are viewed from this perspective as a mechanism to align the incentives of managers with those of shareholders.

Another incentive argument cited in Bognanno (2010) is based on tournament theory. The idea is that high CEO pay levels may increase the effort of those executives below the CEO position who are competing for promotion to the top spot (Lazear and Rosen, 1981). However, reasons for caution against the use of intense competition also exist because competition may impede teamwork and spark counter-productive efforts (Lazear, 1989). The characteristics of the article have indicated some shortfalls and hence, such arguments can never be generalized to all economies and populations as those of Namibia. Some of the shortfalls identified included that, executive compensation referred to in the article of Bognanno only speaks for CEO's pay, in terms of aligning incentives of managers and shareholders by adopting a stock options scheme that fits in well for only listed firms. In addition, tournament theory suited the incentive argument. In congruent, a similar study in a smaller economy, Namibia inclusive of all executive levels and not only CEOs, with different characteristics of population which is Commercial Public Enterprises and not listed on any stock exchange, with different research methodology by collecting data from the primary source was pertinent. Above all, the current study recommend adapting to organisational equilibrium theory as a sustainable incentive in a fast changing and volatile environment.

\subsection{Executive Compensation in Public Enterprises}

Kuepper (2019) discussed many different forms of executive compensation, with a variety of tax benefits and performance incentives. Below are the most common forms:

1. Cash compensation - This is the sum of all standard cash compensation the executive receives for the year. In the proxy statement, the company will list the base salary for each key member of the management team, such as the chief executive officer(CEO), chief financial officer(CFO), legal counsel, director of sales and other divisional heads.

2. Option grants - This is a list of all options granted to the executive; the information includes strike prices and expiration dates. Stock options, if used the right way, could inspire management to maximize shareholder value. However, there is a downside to options compensation. For example, management is awarded significant options grant that is barely out of the money, meaning if the stock price goes up a little, management will be able to exercise options, convert them to common stock and sell the shares to reap a quick windfall.

3. Deferred compensation - This compensation is deferred until a later date, typically for tax purposes. Forms of deferred compensation include retirement plans, pension plans and stock options.

4. Long-term incentive plans (LTIPs) - Long-term incentive plans encompass all compensation tied to performance for tax purposes. Current tax laws favour pay-for-performance compensation.

5. Retirement packages - These are packages given to executives after they retire from the company. It is customary for some executives to receive health benefits upon retirement for years of service, or other reasonable perks. These are important to watch because they can contain so-called golden parachutes for corrupt executives or be payable regardless of whether the company meets its financial objectives or is even profitable. 
6. Executive Perks - These are various other perks given to executives, including the use of a private jet, travel reimbursements, and other rewards. Perks paid out to executives at small companies should be subject to even greater scrutiny because this type of greed is more likely to bankrupt smaller companies or contribute to annual deficits.

Kuepper (2019) explained that internationally and in particular in the USA all executive compensation information can be found in public filings with the Securities and Exchange Commission (SEC). The SEC mandates all public companies disclose how much they are paying their executives, how this amount is derived and who is involved in determining pay.

\subsection{Evaluating Executive Compensation}

Evaluating executive compensation can be a difficult task for the individual investor. Luckily, there are many tools available to make the process easier. These tools automatically parse SEC filings in the USA to pull the numbers and make comparisons designed to give meaning to raw information (Kuepper, 2019).

In the UK a study by Ndzi, (2014) considered the regulation of the determination of executive remuneration as an important foundation that can potentially link executive pay to company performance. The study considered the principles of UK Corporate Governance Code on the determination of executive pay, and the Companies Act 2006's provisions on executive remuneration. Nevertheless, the UK Corporate Governance Code does not make recommendations on the factors that the remuneration consultants should consider in benchmarking. To this effect, Ndzi study adopted a mixed method approach and interviews were conducted to establish the method of executive remuneration benchmarking as there exist no guidelines on benchmarking. Six prominent remuneration consultants where interviewed for which the data was obtained to analyse executive remuneration benchmarking. The findings demonstrated a lack of uniformity in benchmarking practices particularly in the factors considered in selecting comparator companies.

Dever et al., and Farmer (n.d) cited in Ndzi (2014) examined the literature existence on pay for performance in the UK were of the opinion that there is no consistency in the results so far due to the different measures and ambiguous remuneration measures adopted by the researcher. In all fairness to the researchers, companies use these ambiguous performance measures to determine pay, which makes it difficult for the researchers. They recommended a more theoretical guidance in future research on the subject in particular with the choice of performance measures, timeframes, samples, methods and variables.

Meanwhile, a similar study by Deysel and Kruger (2019) have based their exploratory study on the agency theory, which postulates that linking CEO compensation to company performance is a means of reducing agency monitoring costs. Their study takes into account the historical and current trends in CEO compensation, including King III and its "say-on-pay" provision. Deysel and Kruger study have adopted a detailed analysis, using a seven-year time period, was performed at individual company level as well as at sector level and included two measures of company performance, namely market performance (share price) and accounting performance (return on equity, EBITDA and HEPS).

Hence, an adequate platform to conduct both an exploratory and evaluative study of assessing the impact of the compensation packages on the executive performances in the regulated companies or Commercial Public Enterprises in the republic of Namibia where the focus is more on economic performances of a company. In this regard the supportive measures in setting the executive remuneration in Namibia is attached to the Namibia code as established in 2014 and prevailing companies Act of 2004.

In Namibia, particularly the performance agreements of management staff of public enterprises are clearly stipulated in the Public Enterprise Governance Act 2019 (Act no. 1 of 2019 chapter 3: article no.17 as follows:

- The board of a public enterprise must require the chief executive officer to enter into a performance agreement with the board, with due regard to any directives laid down by the Minister under section 4(1) (e). 
- The chief executive officer of a public enterprise must require all senior management staff of the public enterprise to enter into a performance agreement with him or her, with due regard to any directives laid down by the Minister under section 4(1)(e).

- If a chief executive officer or senior management staff member has failed to comply with any provision of a performance agreement which he or she has concluded in terms of this section such failure constitutes a ground for his or her dismissal from the service of the public enterprise, subject to compliance with the rules of natural justice: Provided that such a failure that has been caused by unforeseen circumstances outside the control of the chief executive officer or staff member, does not constitute such a ground.

\subsection{Executive Compensation versus Performance}

One of the most popular ways to evaluate executive compensation as cited by Kuepper (2019) is by comparing pay and performance. Unfortunately, many executives are given raises and bonuses even when their companies are faltering. Comparing pay to stock performance can help companies determine whether executives are overpaid. The specific metric used most often is comparing the change year over year in executive pay increases to the change year in stock price. If the change in the stock price outpaces the change in pay, the executive is not overpaid.

For instance, between 1998 and 2006, Bill Gates' compensation was tied pretty closely to the company's overall performance. When the company makes more money, Gates receives more compensation and vice versa. This is healthy because it provides executives with the incentive to perform well and increase their wealth. Trends are showing executives receiving a higher rate than performance, which can mean overcompensated (Kuepper, 2019). Rewarding for underperformance can hurt investors both in money paid out and incentives to perform.

A case study by Nirenberg, (2018) also concluded that excessive pay is a major problem in the United States, but less so as we look internationally. Table 1 highlights some of the industrial world's comparative position.

Table 1. Average CEO versus Average Worker Compensation (in U.S. Dollars)

\begin{tabular}{|l|c|c|c|}
\hline & & Average & Average \\
\hline & & CEO & Worker \\
\hline Rank & Country & Compensation & Compensation \\
\hline 1 & United States & $12,259,894$ & 34,645 \\
\hline 2 & Canada & $8,704,253$ & 42,253 \\
\hline 3 & Switzerland & $7,435,816$ & 50,242 \\
\hline 4 & Germany & $5,912,781$ & 40,223 \\
\hline 5 & Spain & $4,399,915$ & 34,387 \\
\hline 6 & Australia & $4,183,419$ & 44,983 \\
\hline 7 & France & $3,965,312$ & 38,128 \\
\hline 8 & United Kingdom & $3,758,412$ & 44,743 \\
\hline 9 & Netherlands & $3,576,256$ & 47,056 \\
\hline 10 & Sweden & $3,358,326$ & 37,734 \\
\hline 11 & Norway & $2,551,420$ & 43,990 \\
\hline 12 & Japan & $2,354,581$ & 35,143 \\
\hline 13 & Denmark & $2,186,880$ & 45,560 \\
\hline 14 & Czech Republic & $2,159,300$ & 19,630 \\
\hline 15 & Poland & 561,932 & 20,069 \\
\hline
\end{tabular}

Note. Source: Table constructed with data obtained from AFL-CIO's (2018) Paywatch. 
Perhaps most notably, Japan's CEOs typically receive much less than their status as the third largest global economy would warrant (Kitchen, 2010) as cited in Nirenberg (2018). But it may be a cultural thing. The ultrahigh salaries are considered unseemly in Japan, where promotion is usually from within, avoiding the public displays that frequently accompany American superstar negotiations to place oneself in an egotistically driven exercise to see just how much one can get away with.

Overall Nirenberg (2018) study is an extremely versatile case to teach at all levels due to the nature of the two central issues: the disconnect between pay and performance, which defies the idea of a meritocratic system, and the injustice of such a large disparity between top executives and everyone else. Many questions were embedded in the case that first stimulated the reader to engage with the case while reading it. They also help students prepare for class discussion where there could be a debate-style activity about (a) the growing inequality; (b) the reasons for the negative relationship between pay and performance; (c) the absolute size of the paycheck and what should be done about it, if anything; or (d) whether or not the system of allocating CEO pay is responsible from shareholders' (owners') and societal perspectives.

There are various methods to determine CEO pay. Which one most fairly represents annual earnings? Do organizations' annual earnings tell the whole story? How does an organization justify the enormous retirement or golden parachute payouts that sometimes dwarf the CEO's actual compensation? What other consequences are there of such exaggerated absolute income figures? How might you explain the exit packages even when CEOs were objectively ineffective, such as Ron Johnson at JCPenny? How might you consider the research that demonstrated a negative relationship between pay and performance if you were to establish a pay package for an incoming CEO at a large company? What about a smaller or private company?

The case as mentioned was meant for students to prepare for a class, however it was still relevant for researchers of executive compensation to help prepare researchers to clarify and probe more information from the respondents most especially where face to face interviews are conducted. Again, this may assist the researchers to build on well informed study recommendations in the study concerning executive compensation. Hence a good insight information on the study to assess the impact of compensation packages on executive performances in Namibia CPES where the primary source plays a pivotal role.

The NamCode (2016) highlighted the pay and performance of Executive remuneration in Namibia to include:

- Companies should adopt remuneration policies and practices for executives that create value for the company over the long term. The policies and practices should be aligned with the company's strategy, should be reviewed regularly and should be linked to the executive's contribution to company performance.

- Factors affecting company performance, but outside the control of senior executives, and to which they have made no contribution should only be considered to a limited extent.

In particular to remuneration of management in public Enterprises in Namibia, it is clearly highlighted in the public Enterprises Governance Act No.1 (2019) chapter 18 that the remuneration and other service benefits of the chief executive officer and other management staff of a public enterprise must be determined by the board of the public enterprise with the concurrence of the relevant Minister, with due regard to any directives laid down by the Minister under section 4(1) (e).

\subsection{Peer Comparison}

Another popular way to evaluate executive compensation is to compare one executive to his or her industry peers. While market leaders typically have CEOs who are paid slightly more than others in their industries, the majority of executives should be paid on par with their peers (Kuepper, 2019). Recent study by Gartenberg \& Wulf (2017) presents evidence that social comparison influences both the level of pay and the degree of performance sensitivity within firms. Their study reports pay patterns among division managers of 
large, multi-business firms over a 14-year period. These patterns are consistent with employees comparing pay against both their peers (horizontal comparison) and the chief executive officer (vertical comparison) within their firm. Horizontal comparison also appears to reduce pay-performance sensitivity, in accord with prior theory proposing that performance pay can lead to perceived pay inequity among employees. Taken together, Gartenberg \& Wulf (2017) evidence suggests that agency costs and social comparison jointly influence pay within firms. The evidence also supports the notion that managers of multi-business firms are constrained in the degree to which they can incentivize employees, given the firm-imposed reference group.

There are, however, exemptions to peer comparison when it comes to executive compensation issue. For instance, Kuepper (2019) cited Bill Gates as making more than the average executive in his industry for many years. On this Kuepper argued that sometimes, if the executive is the founder of the company or a high-class CEO, he or she may deserve higher compensation. Since, Bill Gates was both an industry mogul and the company's founder, this may explain why his compensation was comparatively higher. However, significant deviations between these two in standard non-founder CEOs can indicate that they are overpaid. Hence, the commercial Public Enterprises in Namibia cannot be an exemption to Kuepper's recommendation.

\subsection{Executive Compensation Laws}

According to Kuepper (2019) who revealed that there have been many new laws passed in the USA to help satisfy investor concerns over executive compensation. Changes in SEC reporting requirements have forced companies to include an "Executive Compensation Discussion and Analysis" section to accompany future pay documentation in all SEC forms.

Other laws on the USA have been more direct in curbing practices the companies themselves use. One prime example of this was the removal of the deferred compensation tax shelter that helped many executives avoids millions in taxes. Moreover, improvements in other tax loopholes have made it much harder for boards to justify large payouts and hide these payouts from investors (Kuepper, 2019).

In Namibia the remuneration guidelines are stipulated in the Government Notice No. 174 of 12 August 2010 as amended by the substitution for the title to that Government Notice of the following title: "directives in relation to remuneration levels for chief executive officers and senior managers of public enterprises and annual fees and sitting allowances for board members: public enterprises governance act, 2006" as traced in the Government gazette, (2018).

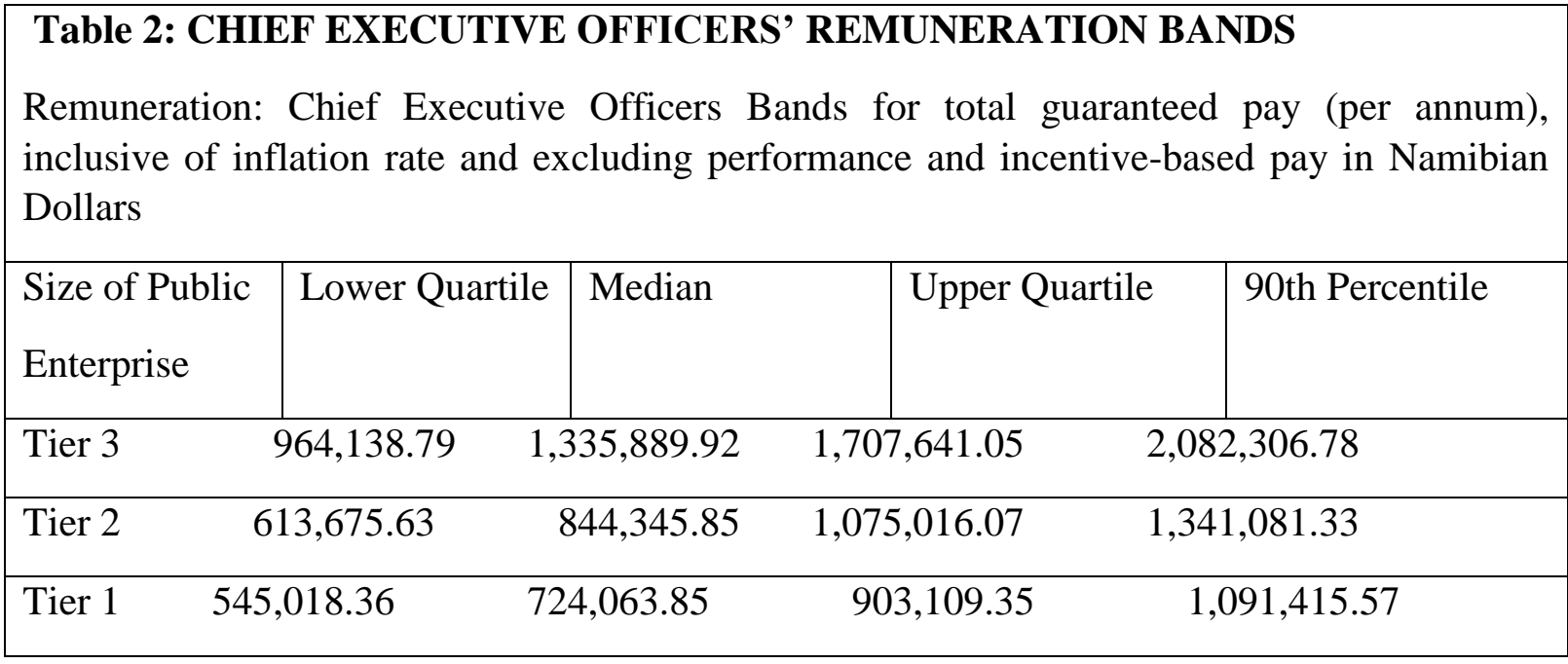

Table 3: Remuneration: Senior Managers

Bands for total guaranteed pay (per annum), inclusive of inflation rate and excluding 
performance and incentive-based pay in Namibian Dollars.

\begin{tabular}{|l|l|l|l|l|}
\hline $\begin{array}{l}\text { Size of public } \\
\text { Enterprise }\end{array}$ & Lower Quartile & Median & Upper Quartile & $90^{\text {th }}$ Percentile \\
\hline Tier 3 & $605,681.01$ & $801,533.95$ & $1,024,584.63$ & $1,249,384.07$ \\
\hline Tier 2 & $505,842.69$ & $669,072.83$ & $832,302.98$ & $1,004,796.55$ \\
\hline Tier 1 & $370,120.28$ & $478,682.04$ & $587,243.80$ & $722,422.82$ \\
\hline
\end{tabular}

Source: Table 2 and 3: Remuneration Guidelines 2018 as traced from the Government notice No. 69 Amendment of Government Notice No. 174 of 2010: Directives in Relation to Remuneration Levels for Chief Executive Officers and Senior Managers of State-Owned Enterprises: Public Enterprises Governance Act, 2006.

\subsection{The Bottom Line of executive compensation}

Gone are the days when de-politicisation of public sector management was a core objective of past reform initiatives; more recent debates urge the state to act as a strong principal when it comes to public sector unity and policy coherence, and consequently make a case for reinvigorating links between the political and managerial sphere (Meyer, Höllerer \& Leixnering, 2018). Meyer et al.,.'s (2018) study used data from Austrian public sector organisations, where they test and confirm the causal relationship of political connectedness of board members and executive compensation. Meyer et al., (2018)'s study further made a distinction between value-based and interest-based in-groups. Hence, Meyer et al., (2018)'s study suggests that only value-based political connectedness has the potential to restore patronage as a control instrument and governance tool. Self-interested and reward-driven patronage, on the other hand, indicated by a strong association of political connectedness and executive pay, refers to the type of politicisation that previous public sector reforms promised to abolish.

As referred by Kuepper (2019), executive compensation is a very important issue for investors to consider when making decisions. An improperly compensated executive can cost shareholders money and can produce an executive who lacks the incentive to increase profits and boost the share price. Meanwhile, the government of a powerful economy country such as the USA is working to curb the problem with new laws that close loopholes and make the process more transparent. Namibia is no exception in overcoming any possible loopholes existing in the practice executive compensation. Hence, a combination with such new analysis tools, investors including the governments are now much more informed.

Zouari et al., (2012) study assessed the impact of CEOs characteristics on earnings management. Their study tests were performed on 153 French listed firms over the year 2008. They studied the French context because it was characterized by weak legal institution, large number of family-controlled firms, and managers usually member of the controlling family. This enable their study to build the study assumption for duality share ownership. Using discretionary accruals as proxy for earnings management, Zouari et al., (2012) study found a significant positive relationship between CEO characteristics and earnings management, suggesting that as reputed CEO is well compensated, he is more afraid to lose his compensation level, therefore his incentive to manipulate firm's earnings increases. Findings also indicated that the dual CEO-chairman relationship advances CEO to manage earnings, particularly when the CEOchairman holds the major proportion of equity ownership in the firm. This finding suggests that CEO-chair accumulates his managerial power and lack of control to extract private yields.

As highly emphasized in the study by Zouari et al., (2012) they outlined that with these corporate scandals 'aftermath, major researches focused on the variables that affect CEOs' earnings management decisions. However, their study added new evidence to the few studiers discussing whether executive managers affect their firm's accounting outcomes. Previous literature have provided little evidence on the extent to which differences in managerial attitudes such as CEO overconfidence and charisma are reflected in earnings 
management (Davidson, Jiraporn, Kim \& Nemec, 2004; DeFond, Hann \& Hu,, 2005; Hribar \& Yang, 2010) as cited in Zouari et al., (2012) study. Other academic researchers have studied concurrent associations among CEO reputation, CEO tenure and CEO duality, and such issues as, corporate governance, firm performance and compensation (Allgood \& Farrell, 2000; Milbourn, 2003; Karuna, 2009).

As defined in Zouari et al., (2012) study earnings management is the use of the flexibility in accounting principles that allow managers to influence reported earnings, thereby causing reported income to be larger or smaller than it would be otherwise. This study contributes to the literature by presenting further evidence that CEO characteristics have significant explanatory power for earnings management. Specifically, this study proposes that the decision making by CEOs can be influenced by their characteristics, in practically their tenure, skill and age.

Finally, Zouari et al., (2012) results came up with new evidence on the relation between CEO expertise and earnings management. It shows that expertise affects positively CEO's behavior to use aggressive earnings management. These findings suggested that reputed CEOs are more likely to manage earnings than less reputed CEOs. This influence intensifies when the CEO holds the largest portion of firm's equity at the same time, he holds the same position as chairman of the board in the firm. Consistently, reputed executive managers are well compensated, and in order to maintain their compensation, they were more willing to manipulate their firm's reported earnings.

Agency theory predicts that managers are motivated by their own interests and states that monitoring is crucial to evaluate their performance. However, it could not reveal why managers engage in earnings management in first place. Watts \& Zimmerman $(1978,1986)$ applied agency theory and developed the Positive Accounting Theory (PAT) which focuses on internal contractual incentives. It was difficult to infer from the study clear answers to questions of interest to both standard setters and investors, such us how CEO's characteristics affect earnings management and what are the channels through which managerial characteristics affect earnings management.

This limitation in Zouari et al., (2012)'s study suggests that there is opportunity for further research on this field. Hence, the study to assess the impact of compensation packages on the executive's performances including both the CEO's and or senior managers with a major focus to Namibia Commercial public enterprises which fill the gaps of a different characteristics of a study population and country economy with less listed companies in Africa. Even though this is a little outdated study, it remains to be an open opportunity to contribute on a similar study literature of the CPEs contribution towards the economic output and sustainability of such organisations operations in totality.

\subsection{Board of director's role in determining executive compensation and its overall impact on executive performances}

In a survey titled 'On point: looking ahead of executive pay practices' by Pearl Meyer (2019: 5, 6), she summarised the oversight roles of compensation committee as follows:

- Compensation committee oversight responsibilities vary by ownership type.

Pay is reviewed for all corporate officers by $50 \%$ of public company respondents compared with only $12 \%$ at private Organisations.

- Most committees $(75 \%)$ are also responsible for no -employee director compensation and executive succession planning (67\%), with $41 \%$ also overseeing leadership and talent development.

- Only $22 \%$ are currently involved in corporate culture oversight. Given the \#me-too movement, pearl Meyer study (2019) expects prevalence in this area to increase going forward.

Conyon (1997) as cited in Kakkar (2013) considered the issue of the directors' compensation and company performance. The effect of remuneration committee on pay has also been seen using a questionnaire survey of thousand largest companies. He found that the director pay tends to be linked to sales growth, which may not be in the interest of shareholders. He concluded that the remuneration committee did not play any role in strengthening the system of governance. 
Jackson (1997) suggested that companies with chief executives who overpay themselves perform badly in terms of profits and share prices. Such companies signal weak governance and lack of alignment between individuals and shareholders' interests. In addition, Kakkar (2013) highlighted the difference between high powered incentive arrangement in UK and USA vis-à-vis those in Germany and Japan. It was concluded CEOs of firms with weaker governance earn high compensation but performance firms remained low.

\subsection{The relationship between compensation package of executives and Performance of Public Enterprises}

Several studies have confirmed that there is a relationship between the compensation of executives and performance. A study conducted by Bussin and Ncube (2017) revealed that there is a positive relationship between CEO and CFO remuneration (fixed pay and short-term incentives) and company performances. Company size appears to be the key determiner of fixed pay in SOEs. The positive relationship was mainly noted on absolute profitability measurements like EBITDA (earnings before interest, tax and depreciation and amortisation) and net profit.

In similar studies by Callan and Thomas (2014) and Mahoney and Thorne (2004), as cited in Eriana (2019), it was revealed that executive compensation, as a determinant factor of corporate sustainability, is designed to motivate managers to implement better and disclose more corporate responsibility activities that are tightly linked to company financial performance. The views shared in the above-mentioned studies are the perspective of both shareholder and stakeholder in consideration that executive compensation is designed by the board of directors to encourage managers to serve multiple stakeholders' interests, an assertion supported by stakeholder theory (Eriana 2019).

Similarly, Bezuidenhout, Bussin and Coetzee's (2018) study suggests that there should be a relationship between the CEO's remuneration and SOEs' performance. The high CEO remuneration despite declining SOE performance during the study period was a concern. Moreover, the evidence of a negative relationship between the CEO's remuneration and measures of the SOEs' performance suggests that the CEO's remuneration is not aligned with all of the SOEs' performance measures. This may be a contributing factor with regards to poor performance of South African SOEs (Bezuidenhout, Bussin and Coetzee, 2018). Based on the research findings, a framework merging financial measures needs to be developed and formalised with a link to SOEs' objectives. The frameworks, with clear performance measures linked to them, should be effectively monitored under a governance structure.

In addition, Suman, Kimberly and Yezen (2014) found that the structure of fixed versus incentive-based compensation impacts customer satisfaction. However, this was not the first paper to investigate the relationship between the sensitivity of CEO compensation and customer satisfaction where it is emphasised that performance is a precondition for customer satisfaction. As a further limitation in this context, the study by Suman et al., (2014) highlighted the stakeholder theory but left out the shareholder and/or agency theory interests that strengthen the need for organisations to recognise the need of applying organisational equilibrium theory to all the executive remuneration matters.

It is worthy of note a study conducted by Onuorah, Okeke, and Ikechukwu (2019), which analysed the influence of performance-based compensation, competency-based compensation and equity-based compensation on employee performance in the Nigerian organisations revealed the following results: Equity-based compensation has no negatively significant effect on employee performance in Nigerian organisations; Competency-based compensation has no negatively significant effect on employee performance in Nigeria's organisations; and performance-based compensation has no negatively significant effect on employee performance in Nigeria's organisations. Employees' willingness to stay on the job largely depends on compensation packages of the organisation (Armstrong, 2003). In an attempt to ensure employee optimal performance and retention, organisations need to consider a variety of appropriate ways to reward the employees to get the desired results (Falola, Ibidunni and Olokundun, 2014). 
In addition to Nigeria case is a study by Oyerogba (2016) whom in his study empirically examined the impact of executive compensation on firms' profitability for the listed companies in Nigeria using a period of ten years ranging from 2004 to 2013.Specifically, Oyerogba study investigated the impact of directors' cash incentives, non-cash incentives and bonus issue of share on earnings per share of the selected companies. Oyerogba study relied on the secondary data extracted from the audited financial statement of a sample of 70 companies purposefully selected from the 198 listed companies in Nigeria. Both descriptive and inferential statistics were carried out. Oyerogba study results revealed that a significant positive relationship exists between the directors' cash incentives, bonus issue of share and earnings per share. The relationship between non cash incentive and earnings per share was insignificant. Oyerogba study recommended to the management that weight should be assigned to the variables in that order. The policy makers also need to provide adequate regulation on the determination of remuneration of the directors of listed companies in Nigeria.

The main justification for Oyerogba (2018)'s study was that many of the previous empirical studies focused on cash incentive (O'Sullivan, Percy, \& Stewart, 2008; Ongore, 2011) which has been heavily criticized as lacking ability to promote efficiency (Melvin, \& Hirt, 2005; Mallin, \& Michelon, 2011; Limpaphayom, \& Connelly, 2004). Non-cash payment on the other hand has suffered neglect in empirical studied arising from the general believe that non-cash payment is potentially less fully transparent, given the hard to value nature of the non-cash compensation package. Listed companies are being encouraged to adopt equity-based incentive known as performance-based incentive. In line with agency theory, Kim and Gu (2005) as cited in Oyerogba (2018) suggested that a compensation system based on managerial performance would be a better solution to deteriorating performance of corporate organization because perfect monitoring may be impossible or too expensive. Thus, investigating its impact on profitability will assist the regulatory authorities in recommending it to the directors of listed companies in Nigeria.

Nevertheless, Oyerogba (2016) recommended further studies that employ the use of primary data on the same topic to obtain the opinion of respondents to test the reliability of the secondary data already documented. Hence the necessity to conduct similar study to fill this gap and also focused on a different descriptive of population the Commercial Public Enterprises in a smaller economy country namely Namibia in comparison to Nigeria being the biggest economy on African continent.

Bognanno, M. (2010) composed an article characterizes the basic framework within which CEO pay is viewed, and presents the principal arguments characterizing this debate. According to Boganno study the compensation of CEOs is generally viewed within an agency framework (The gist of agency theory is found in the Bible, John 10:12: 'He who is a hired hand, and not a shepherd, who is not the owner of the sheep, sees the wolf coming, and leaves the sheep and flees, and the wolf snatches them and scatters them'). The separation that exists between the owners and managers in corporations gives rise to an agency problem in which managers have an incentive to pursue their personal interests over the interests of shareholders.

The increase in the components of pay that are linked to firm performance, stock option schemes for example, are viewed from this perspective as a mechanism to align the incentives of managers with those of shareholders. Another incentive argument in Boganno study was based in tournament theory. The idea is that high CEO pay levels may increase the effort of those executives below the CEO position who are competing for promotion to the top spot (Lazear and Rosen, 1981) as cited in Boganno (2018) study. However, reasons for caution against the use of intense competition also exist because competition may impede teamwork and spark counter-productive efforts.

The characteristics of the article have indicated some shortfalls and hence such arguments can never be generalised to all economies like Namibia. Firstly, the executive compensation referred to in the article only speak for CEO's pay alone that predominantly talk in terms of aligning incentives of managers and 
shareholders by adopting a stock options schemes that are more evident in developed nations such as the US firms. In addition, tournament theory suited the incentive argument. Therefore, a similar study in a different geographical area i.e. a small economy country and developing nation in Africa called Namibia, consideration of all executive levels and not only CEO's in Commercial Public Enterprises, using a mixed methodology and primary source. Further the study recommend for the adoption of organisational equilibrium theory as a sustainable incentive in a fast changing and volatile environment organisations operates.

Ramachandran (2018) paper had also explored the issues in executive compensation with special reference to corporate financial performance measured in terms of Profit After Tax (PAT), Total Revenue, Total Assets, Net worth and Market Price Returns of the Company. Ramachandran study was based on published executive compensation data collected from the companiese ${ }^{\text {e }}$ annual reports. The Ramachandan study period spans five financial years from 2011-2012 till 2015-2016. The automobile companies which form part of NIFTY are selected for the study. The NIFTY consists of well-diversified 50 company's index accounting for 12 sectors of the economy.

Ramachandran's study results concluded that there is a negative correlation between the executive remuneration and the market price returns of the selected sample companies and found an insignificant relationship between financial performance measures and the executive compensation through multiple regression analysis. It was interesting to note that all through five financial years, the data shows that the executive remuneration is negatively correlated with Market Returns of Equity Shares. For all the years considered for the study, it was observed that, the null hypothesis is not rejected at $5 \%$ level of significance since the p-value is greater than 0.05. The regression model is considered to be fit if there is no auto correlation. This finding was in line with the study by Hay Group analysed CEO compensation mix across the globe, to find that Indian CEO pay lags behind in its correlation to performance, which should reflect on the wealth of the shareholders represented by the market price returns.

As emphasised in Ramachandran (2018) study a tremendous amount of research had explored the relationship between executive compensation and the company's performance and linked the same with corporate governance issues. There were around 300 studies under this topic which were reviewed by Gomez-Mejia (1994) and Gomez-Mejia and Wiseman (1997).Almost all empirical studies on CEO pay conducted in the past utilized U.S. data and have focused on U.S. contexts, hence a need to explore this topic in other developing countries Ramachandran covered at least one of the fast growing developing Nation in Asia and the current study is contributing from a small developing country in Africa namely Namibia.

Further elaborations on the linkage between the company performance and corporate issues Ramanchandran (2018) study identified the two conflicting views on executive compensation literature. One school of thought, the Managerial Power Perspective claims poor governance is the cause of large levels of executive compensation granted by companies. As per this view, executive management takes compensation from shareholders due to entrenchment. The conflicting other school claim CEOs merely receive the market value of their labour.

Also, important to note that Ramanchandran (2018) study was strengthened by another study by Raithatha and Komera (2016) where they studied the relationship between executive compensation and firm performance among Indian firms collecting data from 2002 till 2012. Their study evidence suggests that firm performance measured by accounting, as well as market-based measures, significantly affects executive compensation. They also tested for the presence of persistence in executive compensation by employing the system- generalised methods of moments (GMM) estimator and found the significant persistence in executive compensation among the sample firms. Further, they reported the absence of pay-performance relationship among the smaller sample firms and business group affiliated firms. Thus, as clearly outlined in 
Ramachandran the Raithatha komera (2016) findings cast doubts over the performance-based executive compensation practices of Indian business group affiliated firms.

Though the many studies have been conducted to study the managerial pay and firm performance the research has generally been limited in Indian Context with specific reference to different sectors. An attempt has been made in Ramachandran study to contribute to the executive pay-performance literature with latest data set (2012-16) from the Automobile Sector in India. Similarly, the limitation indicated in the under discussed papers in India has had activated this study to contribute from other smaller developing countries such as Namibia to executive compensation and performances literature. Further contribute using the mixed methods quantitative and qualitative sourcing from primary data instead of limiting to secondary data from a different sector the Commercial Public Enterprises and herewith representing major Namibia economic sectors namely; infrastructure development, manufacturing and Agriculture; Education; Health and Tourism and Fishing.

Lipson et al., (2012)'s study assessed the effect that asset securitization has on executive compensation. Securitization is the process whereby firms "sell" financial assets in transactions that bear many economic characteristics of a loan. Scholars and policy makers have expressed concern about the agency costs associated with such transactions, including that they create opportunities for managers to loot companies that engage in them. Lipson et al., (2012)'s study focus was on non-financial-services firms, and construct a dataset of over 15,000 firm-year observations, comparing the CEO pay of securitizing firms $(1,051)$ to those that do not (14,301). Lipson et al., (2012)'s study drew data from various sources.

Executive compensation is from the "“"ExecuComp"” database59, financial accounting information is from the "“COMPUSTAT"” database60, stock returns are from the "“CRSP"” database61 and securitization details are hand collected from $10-\mathrm{K}$ and $8-\mathrm{K}$ filings accessed through Direct EDGAR Reserachers concluded that asset securitization is unlikely to have a material effect on executive compensation. Panel OLS fixed-effects regressions, year-on-year change regressions, matched sampling and sub-sampling analyses showed that securitizers do not, in fact, pay more than non-securitizers. This, in turn, suggests that whatever its other strengths or weaknesses, securitization by non-financial-services firms is unlikely to lead to agency costs hypothesized in the literature.

As per literature cited in Lipson et al., study including Kevin Murphy has noted "CEO pay research has grown even faster than CEO paychecks, skyrocketing from 1-2 papers per year prior to 1985 to 60 papers in 1995.Frydman and Saks (2010) report that executive pay increased moderately during the mid-1970s and rose at a faster rate in the subsequent two decades, reaching an average growth rate of more than 10 percent per year from 1995 to 1999.23 "many argue that executive compensation reflects reasonable returns to performance. For example, at least since the 1970s, CEO compensation has grown with firm capitalization, suggesting that managers may be reaping the rewards of their firms' prosperity. This view has encountered trouble, however, when measured against historic performance.

During the late 1950s and "60s, firms grew but executive compensation did not.31 Still others argue that as firms have grown in size and complexity, CEOs have had to develop (and deploy) greater general management skill.32 yet, it seems more likely that skill levels improved incrementally over time. It is unlikely that skill-levels began to spike suddenly, coincident with executive compensation.33 Thus, while there is little doubt that CEO pay has increased dramatically since the 1970s, no consensus explanation has yet emerged.

Lipson et al., (2018) cautioned that their study results were based only on observations of non-financial services and therefore recommended further studies in similar context. Hence, a study is conducted with non-securitised organisations in Namibia the listed public enterprises with the Ministry of Public Enterprises 
both categorised commercial and non-commercial public enterprises in Namibia for thesis research and pilot study for publication purposes. This study builds on this literature, making both methodological and empirical contributions. Unlike other papers on this, therefore, this study looks not only at securitisation, but also compare compensation packages impact at Non securitisation Public Enterprises in different economic sectors.

In conclusion a literature review and recent study by Gao (2019) has sorted out and summarizes literatures on executive compensation gap and enterprise performance, and puts forward the direction of further exploration. Firstly, Gao's paper sorted out relevant literature from three perspectives: the relationship between executive compensation and corporate performance, internal compensation gap and corporate performance, and external compensation gap and corporate performance. Secondly, this paper reviews the research on executive compensation gap and enterprise performance. Finally, Gao paper proposed the future research direction of executive compensation gap and enterprise performance.

Gao (2019)'s paper adopts the method of literature review to sorts out and summarizes literatures on executive compensation gap and enterprise performance, and puts forward the direction of further exploration. In conclusion, executive pay gap in this field and business performance research to present the following characteristics: 1) the research object, from the sample area in the United States, in Europe, to developing countries, in China also gradually to the addition of Chinese characteristics such as property right nature of the research, and international comparisons are emerging. 2) In terms of research methods, theoretical research and empirical research go hand in hand.

Unfortunately, at present, most domestic researches are empirical data sources of public information of listed companies, so detailed data related to the fairness of executive compensation distribution process are not available, which weakens the accuracy and effectiveness of the research results. In view of this Gao study recommended that, future research should not only carry out empirical research based on the secondhand data published by listed companies, but also conduct in-depth field investigation to obtain specific and in-depth primary data and promote the in-depth development of research. The existing researches as referred in Gao's study mostly study the executive compensation gap at a single level, and the empirical model design also lacks the consideration of cross-level issues. Scholars still lack significant results from the perspective of "contingency effect". How the key contingency factors represented by the knowledge cooperation needs of the executive team affect the relationship between the executive pay gap and enterprise performance needs to be discussed in depth on the premise of national conditions. Hence, it's a high reasonable sense to conduct a study assessing the impact of compensation package in Namibia public enterprises which reckons the limitations of previous studies in terms of the country economy which is quiet young only thirty years, prioritising the usage of primary source, multi sector of enterprises and levels of executives contained in the Commercialised Public Enterprises in Namibia

\subsection{Methodology}

This study adopted a mixed-methods approach. The mixed methods approach is known for conducting studies aimed at uncovering deep aspects in a human dynamic of operations (Saunders, Lewis, \& Thornhill, 2016). In this case it was the remuneration package for executives and its influence on the performance of Commercial Public Enterprises in Namibia. In the context of the mixed research approach, the study followed an explorative, descriptive and contextual research design. The research design chosen enabled the researcher to achieve the purpose and objectives of the study. In this chapter, the research approaches are described in terms of design, methods, population, instruments and procedures used for data collection as well as procedures used during the data analysis, as follow:

To determine the relationship between compensation package of executives and the performance of commercial PEs in Namibia 


\subsection{Population}

The population of CPEs in Namibia is around 22, however, the 2016 Hybrid Governance Model segregated them into commercial, non-commercial and financial institutions. This study focuses on the commercial CPEs, which has a targeted population of 22 Commercial CPEs reporting to the Ministry of Public Enterprises (MPE). Within the 22 CPEs under the MPE, there are three different tiers of companies, which are grouped by their size, revenue and market share.

\subsection{Sample Size}

The target population of this study was the CEO/MD and Board Chairpersons of twenty-two largest Commercial SOEs in Namibia, which includes entities such as the Namibia Airports Company, Namibia Institute of Pathology, Namibia Ports Authority, Namibia Post and Telecommunications Holdings, Namibia Power Corporation, TransNamib Holdings, Zambezi Water Front, etc. These entities report directly to the Public Enterprise Ministry as articulated in the Public Enterprise Governance Act 2018. Therefore, the sample size of the study was 44, and includes the CEO/MD and Board Chairperson of each of the twentytwo (22) Public Enterprises listed.

Each of the 22 commercial public enterprises was represented by the CEO/MD and/or Senior manager who had completed the structured questionnaire designed for CEO/MD (agent). Simultaneously the Board Chairperson (Principal) of each of the 22 were given a separate questionnaire designed for them. The CEO/MD is purposefully selected because they are the executives of the Public Enterprises, knowing that this study is for executives, while the board Chairpersons were involved because they are the ones supervising the CEO/MD. This made the CEO/MD and the board chairpersons the right people to participate in this study as respondents, for them to explain their experience concerning this critical issue of Executive compensation package and its impact on the performance of the commercial public enterprises in Namibia.

A list of executives and board chairpersons from all listed commercial PEs were sought from the Department of Economic and Corporate Governance in the Ministry of Public Enterprise that helped in determining the respondents' direct contact details. Once they were identified, each CEO/MD of the commercial Public Enterprises and each Chairperson were invited to participate in the study.

\subsection{Research Instruments}

The researcher used multiple instruments and techniques within the qualitative and quantitative approaches of data collection. These included structured questionnaires, secondary data and documentary analysis. The study used structured questionnaires for CEOs and Board Chairpersons to collect data on the compensation packages of executives including the successes, benefits and limitations of compensation packages on the executives' performance. The study used documentary analysis to operationalize the PEs' performance data into validated measurable items related to the availability of the recent financial information, profitability, tax and dividend payments, and the financial support received from government. The self-administered questionnaires consisted of four sections which began with the demographic characteristics, followed by their understanding of compensation packages, benefits of compensation packages, success and limitations of the compensation packages.

\subsection{Data Collection Procedure}

The researcher first sought permission through cover letters to the Executive Director of the Ministry of Public Enterprises and through informed consent from participating CEOs and Board Chairpersons. The primary data for the research was collected directly through from structured questionnaires and PE's websites. The structured questionnaire survey was carried out via a combination of face-to-face, telephonic and email survey. Follow-up contact was made telephonically and through e-mails was done to encourage the participants to completely fill the questionnaire to avoid any issues of missing data. The data on the performance of the Commercial PEs was collected from published Annual Reports of the respective company from its official website which has already published and certified by the IPPR as well as the 
government of Namibia was used to strengthen the reliability and validity. The certified data used is importance to make sure that the researcher does not change or add to the data to compromise the validity and reliability.

\subsection{Data Analysis}

When the questionnaires were returned, they were screened to determine if they were completed properly. Those not properly completed were removed from the questionnaires that were analysed. After the screening had been completed, a code book was developed, which was used for coding the questionnaires. The data was captured in the IBM Statistical Package for Social Scientists (SPSS) version 26 for analysis. While, IBM SPSS Amos version 23 was used in the Bootstrapping Path Analysis.

The quantitative data analysis was also conducted in three steps. In the first phase, descriptive statistical analyses were carried out. The descriptive analysis was used to describe the characteristics of the study sample and the performance profile of the PEs, as well as check the variables for any violation of the assumptions underlying the statistical techniques that were used to address the research questions (Pallant, 2013). While, the second step, included factor analysis, which was critical to the modification of variables for multivariate analyses and inference. The factor analysis involved statistical analyses that explored underlying relationships between the variables. The third phase, involved inferential multivariate statistical analyses that were used to address the research objectives.

The study then employed Bootstrapping Path Analysis in SPSS AMOS to establish if there were any significant relationships and effects between the PE's performance data and the executive compensation data collected from the survey. The study follows Kline (2011)'s suggestion of using bootstrapping on the testing of models based on non-normal data, based on the study's small sample size (less than 50) (Byrne, 2016). Bootstrapping is a statistical procedure that falls under the broader rubric of resampling, where the models are tested using normal theory Maximum Likelihood (ML) estimation, but using nonparametric (distribution-free; no assumption of normality) bootstrapping (Kline, 2011).

Furthermore, Byrne (2016) noted that as the sample size decreases and nonnormality increases, researchers are faced with a growing proportion of analyses that fail to converge or that result in an improper solution. As such, when data is non-normal, model fit indices such as the Tucker-Lewis Index (TLI: Tucker \& Lewis, 1973) and the Comparative Fit Index (CFI; Bentler, 1990) yield values that are modestly underestimated (Byrne, 2016). As such, bootstrapping serves as a resampling procedure by which the original sample is considered to represent the population (Kline, 2011). With multiple subsamples of the same size as the parent sample, then drawn randomly, with replacement, from this population in order to provide the data for empirical investigation of the variability of parameter estimates and indices of fit (Byrne, 2016).

The bootstrap Path Analysis procedure in SPSS AMOS provides a mechanism for addressing situations where the ponderous statistical assumptions of large sample size and multivariate normality may not hold (Bryne, 2016, p. 369). Additionally, the advantage of bootstrapping in SEM is that it results in an automatic refinement of the standard asymptotic theories (e.g., higher-order accuracy) from samples with moderate (but not extremely small) sizes (Yung \& Bentler, 1996, p. 223). The study used Gaskin \& Lim (2016) AMOS estimation macros and plugins that uses the Pattern Matrix output from SPSS Statistics' Exploratory Factor Analysis (EFA) to do the anlysis in SPSS AMOS. While, the Bootstrap Procedure suggested in Bryne (2016) and the EFA procedure by Pallant (2013) was followed. The results from the Bootstrapping Path Analysis were then used to answer the three objectives of the study.

\subsection{Ethical Considerations}

To carry out this research, ethical clearance was requested from the University and the bonafide letter was successfully granted. Also, granted were letters of both permission and support sought from the mandated Ministry of Public Enterprises, in particular from the Permanent Secretary though the Directorate of 
Governance and Financial Advice enabled the researcher to successfully carry out the study. The Ministry of public Enterprises letters were of great help in acquiring the participants' permission, however, all the participants were required to sign a letter of informed consent. Participants were also informed of their right to withdraw their consent at any time if they were not comfortable. All data and personal information were kept confidential as no identifying information were required in the questionnaire. Participants were given a choice not to answer any questions that they may not have been comfortable with. Privacy and wishes of the participants were respected at all times. The data collected is to be kept for five year before it gets destroyed by shredding and burning.

\subsection{Results and findings}

The purpose of this paper was to investigate the relationship between compensation packages and the performance of executive officers in commercial Public Enterprises in Namibia. As such, the study collected data from the CEO/MD and Board Chairperson of each of the twenty-two (22) Commercial Public Enterprises reporting directly to the Public Enterprise Ministry as articulated in the Public Enterprise Governance Act 2018, which made it 44 participants. The findings guided by the paper's research objectives as follow:

- To determine the relationship between the compensation package of executives and the performance of commercial PEs in Namibia

\subsection{Performance Profile of the Commercial Public Entities in Namibia}

This section presents findings from the data on the performance of the Commercial PEs collected from published Annual Reports of the respective company from its official website. The study collected information from all 22 entities listed under the Public Enterprises Act of 2018. However, only 16 CEOs and 7 Board Chairpersons from the PEs sought responded. As such, Table 4.1 presents the Performance Profiles of PEs that responded to the questionnaire survey.

The Public Enterprise Annual Rankings is a new IPPR publication developed which appears in the first quarter of each year (IPPR, 2020). The rankings are based on an assessment of commercial state-owned enterprises using information that has been made available to the general public (IPPR, 2020). Additionally, the study uses the gazetted remuneration guidelines for public enterprises, which divides PEs into three tiers: Tier 1, Tier 2 and Tier 3. Findings in Table 4.1 indicated the performance metrics of Commercial Public Entities, which were used in the Annual Public Enterprises ranking report by IPPR (2020). Three different categories are according to revenue, number of employees, their skills and total assets, with the executives and board members in the highest tier (Tier 3) companies earning the most, with the compensation packages of CEOs regulated to a maximum of $\mathrm{N} \$ 1,6$ million. The entities in this category includes NamPower, NamPort, Telecom, RCC, Air Namibia, Telecom, TransNamib, NamPost and MEATCO

Table 4.1: Performance Profile of the Commercial Public Entities in Namibia

\begin{tabular}{|l|l|l|l|l|l|l|}
\hline $\begin{array}{l}\text { Remuneration } \\
\text { Tier }\end{array}$ & Public Enterprise & $\begin{array}{l}\text { Availability of } \\
\text { Information }\end{array}$ & Profitability & Tax & Dividends & $\begin{array}{l}\text { Financial } \\
\text { support }\end{array}$ \\
\hline & AGRIBUSDEV & Full AR for FY16/17 & Loss-making & None paid & None paid & $\begin{array}{l}\text { Budget } \\
\text { support } \\
\text { required }\end{array}$ \\
\hline $\begin{array}{l}\text { Tier 1 (max N\$ } \\
\text { million) }\end{array}$ & AMTA & None & Loss-making & None paid & None paid & $\begin{array}{l}\text { Budget } \\
\text { support } \\
\text { required }\end{array}$ \\
\cline { 2 - 7 } & Zambezi Waterfront & None & Loss-making & None paid & None paid & $\begin{array}{l}\text { Budget } \\
\text { support }\end{array}$ \\
\hline
\end{tabular}




\begin{tabular}{|c|c|c|c|c|c|c|}
\hline & & & & & & required \\
\hline \multirow{7}{*}{$\begin{array}{l}\text { Tier } 2 \text { (max } N \$ \\
1,3 \text { million) }\end{array}$} & $\begin{array}{l}\text { Epangelo Mining } \\
\text { Company }\end{array}$ & None & Loss-making & None paid & None paid & $\begin{array}{l}\text { Budget } \\
\text { support } \\
\text { required }\end{array}$ \\
\hline & NamCor & Full AR for FY16/17 & Profitable & Tax paid & None paid & $\begin{array}{l}\text { None } \\
\text { budgeted }\end{array}$ \\
\hline & $\begin{array}{l}\text { Namibia Airports } \\
\text { Company }\end{array}$ & Full AR for FY15/16 & Loss-making & None paid & None paid & $\begin{array}{l}\text { None } \\
\text { budgeted }\end{array}$ \\
\hline & $\begin{array}{l}\text { Namibia Wildlife } \\
\text { Resorts }\end{array}$ & None & Loss-making & None paid & None paid & $\begin{array}{l}\text { None } \\
\text { budgeted }\end{array}$ \\
\hline & $\begin{array}{l}\text { National Fishing } \\
\text { Corporation of } \\
\text { Namibia }\end{array}$ & Full AR for FY16/17 & Profitable & Tax paid & $\begin{array}{l}\text { Dividend } \\
\text { paid }\end{array}$ & $\begin{array}{l}\text { None } \\
\text { budgeted }\end{array}$ \\
\hline & NIP & Full AR for FY17/18 & Profitable & Tax paid & $\begin{array}{l}\text { Dividend } \\
\text { paid }\end{array}$ & $\begin{array}{l}\text { None } \\
\text { budgeted }\end{array}$ \\
\hline & $\begin{array}{l}\text { Windhoek Country } \\
\text { Club }\end{array}$ & Full AR for FY18/19 & Profitable & Tax paid & $\begin{array}{l}\text { Significant } \\
\text { dividend } \\
\text { paid }\end{array}$ & $\begin{array}{l}\text { None } \\
\text { budgeted }\end{array}$ \\
\hline \multirow{7}{*}{$\begin{array}{l}\text { Tier } 3 \text { (max } N \$ \\
1,6 \text { million) }\end{array}$} & Air Namibia & None & Loss-making & None paid & None paid & $\begin{array}{l}\text { Loan } \\
\text { guarantee } \\
\text { granted }\end{array}$ \\
\hline & Meatco & Full AR for FY18/19 & Loss-making & None paid & None paid & $\begin{array}{l}\text { None } \\
\text { budgeted }\end{array}$ \\
\hline & \begin{tabular}{|l} 
Mobile \\
Telecommunication \\
(NPTH)
\end{tabular} & Full AR for FY16/17 & Profitable & $\begin{array}{l}\text { Significant } \\
\text { tax paid }\end{array}$ & $\begin{array}{l}\text { Significant } \\
\text { dividend } \\
\text { paid }\end{array}$ & $\begin{array}{l}\text { None } \\
\text { budgeted }\end{array}$ \\
\hline & NamPower & Full AR for FY18/19 & Profitable & $\begin{array}{l}\text { Significant } \\
\text { tax paid }\end{array}$ & $\begin{array}{l}\text { Significant } \\
\text { dividend } \\
\text { paid }\end{array}$ & $\begin{array}{l}\text { None } \\
\text { budgeted }\end{array}$ \\
\hline & NamWater & Full AR for FY16/17 & Profitable & Tax paid & $\begin{array}{l}\text { Dividend } \\
\text { paid }\end{array}$ & $\begin{array}{l}\text { None } \\
\text { budgeted }\end{array}$ \\
\hline & $\begin{array}{l}\text { Roads Contractor } \\
\text { Company }\end{array}$ & None & Loss-making & None paid & None paid & $\begin{array}{l}\text { Budget } \\
\text { support } \\
\text { required }\end{array}$ \\
\hline & TransNamib & None & Loss-making & None paid & None paid & $\begin{array}{l}\text { None } \\
\text { budgeted }\end{array}$ \\
\hline
\end{tabular}

Table 4.1 findings indicated that the performance profile of NamPower indicates the most ideal state for a Tier 3 public enterprise, which includes up to date financial statements (Full AR for FY18/19). The review of the annual report indicating the entity was not depending on the national budget and little to no loan guarantees from government. In addition, the Tier 3 entity should be profitable with a documented declaration of significant tax and dividend payments to government. Table 4.1 also indicated that the second tier PEs included in the sample includes Epangelo, NamCor, NAC, NWR, FISHCOR, NIP and Windhoek Country Club. Others include AgriBank, DBN an NBC. The maximum regulated salaries of CEOs in Tier 2 
are pegged at $\mathrm{N} \$ 1,3$ million. The findings from the sample indicated that Windhoek Country Club (WCC) had the most exemplary performance in 2019 with up to date audited financial statements (Full AR for FY18/19). As well as, recording a profit for the year and having fully paid their tax obligations. The annual report indicated a significant dividend pay-out of N\$ 6 million in 2019.

Subsequently, the lowest compensation tier (Tier 1) with a salary packages of CEOs pegged at mostly N\$ 1 million, includes companies like New Era Publication Company, Electricity Control Board, Meat Board of Namibia, Namibia Qualification Authority (NQA), and Namibia Tourism Board (NTB) among others. However, the sample included AgriBusDev, AMTA and Zambezi Waterfront. In terms of performance, AgriBusDev had the best metrics under this category, with most of its budget supported by central government and its financial information updated to the end of 2017 (Full AR for FY16/17). However, according its annual report of 2017 some of the Green Scheme under its portfolio were loss-making, which affected its profitability. As such, no tax or dividends were paid by the public enterprise in the year 2017 .

Under the current performance framework, the task of strategic directions and operations is placed in the hands of the respective Boards of Directors for the PEs and their management. Hence, once the Board of Directors is appointed, the performance of the PE depends on the agency relationship between the Board and management. The effectiveness of these agency relationships has resulted in some PEs performing, while some have not. As such, Table 4.2 presents the Hierarchical Cluster Classification in SPSS version 26 to assess and group the public entities based on their performance profiles.

Table 4.2: Proximity Matrix Assessment of the Commercial Public Entities based on their Performance Profiles

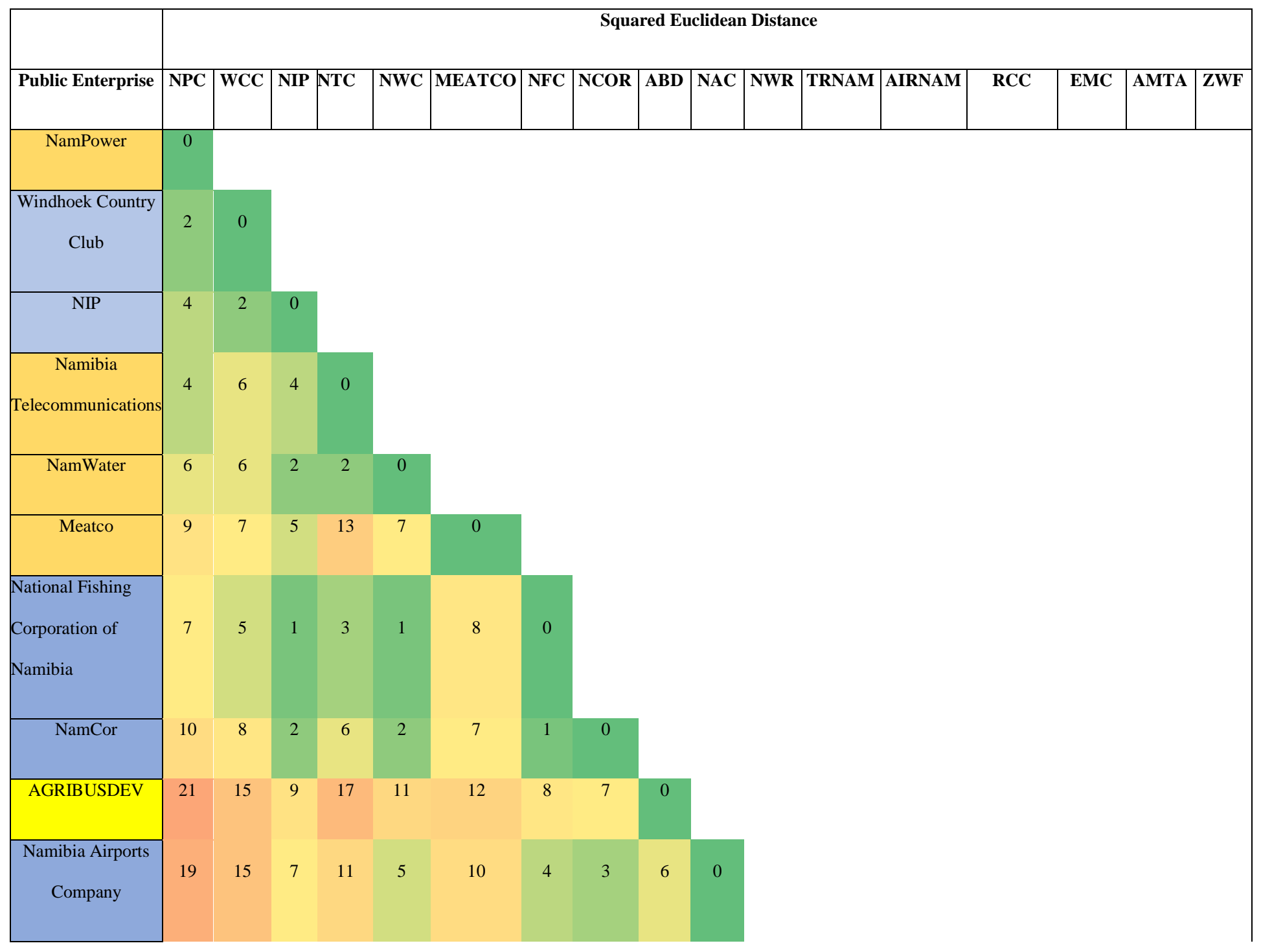




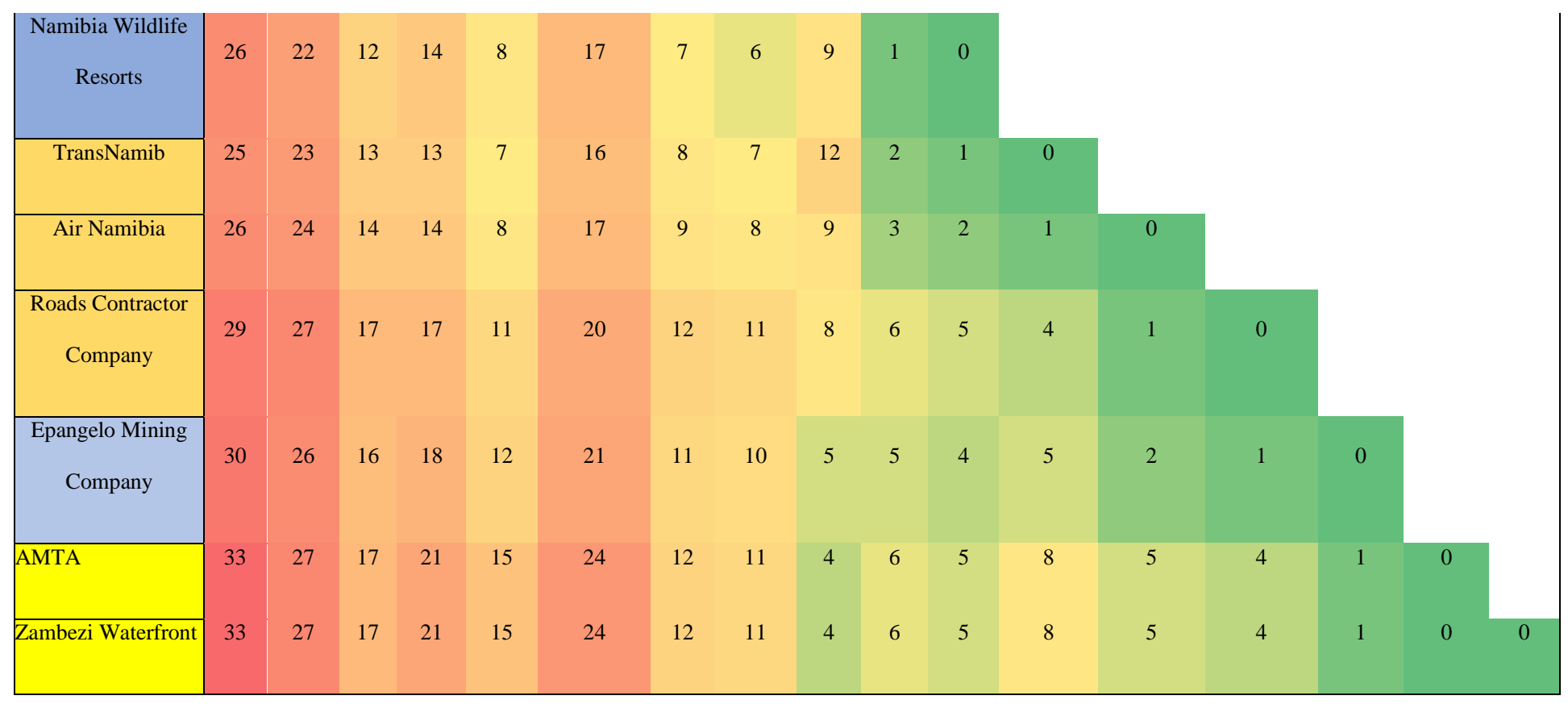

Tables 4.2 shows the performance ranking of the Commercial PEs using a descending order dissimilarity matrix of the entities to the top performer, NAMPOWER. The findings indicate that Windhoek Country Club with a proximity of 2 is closest to NamPower's performance for the year 2019. While, Zambezi Waterfront with a proximity of 33, had the worst performance metrics relative to NamPower in 2019. Additionally, the public enterprises were color-coded based on their regulated compensation packages. The findings indicated that NamPower CEO's performance deserves to be in Tier 3 (orange). While, the high dissimilarities of TransNamib, Air Namibia and RCC qualifies their compensation packages to be in the Tier 1 ranges due to their poor performances.

Additionally, Tier 2 entities like WCC and NIP which outperformed some in Tier 3, should have their compensation packages and bonus aligned to those of their counterparts in Tier3 such as NTC, NamWater and MEATCO. In the same light, AgriBusDev performance for 2019 qualifies a Tier 2 compensation package. With, Epangelo deserving Tier 1 salaries package until it improves its performance to match the NamPower performance. Lastly, AMTA and Zambezi Waterfront had the least favourable performance in the year and their compensation should be the least among the public entities. As result, the comparison of the survey feedback from AMTA and the answers from NamPower executive will shed light into the complexities of the agency relationships of commercial public entities in Namibia.

\section{3.. Demographic Information of the Respondents}

The data was collected through a survey questionnaire, which involved face to face structured interviews from executives and board chairpersons of each of the 22 Commercial PEs. The study had a response rates of $77.2 \%$ for Executives (17) and 36.4\% (8) for Board Chairpersons. The executives included 12 Chief Executive Officers (CEOs) and 5 Deputy or Acting (DCEO). Table 4.3 presents the summary of the demographic information of the respondents.

Table 4.3: Demographic Information of the Respondents

\begin{tabular}{|ll|cl|cc|cc|}
\hline & \multicolumn{2}{|c|}{ Tier 1 } & \multicolumn{2}{|c|}{ Tier 2 } & \multicolumn{2}{c|}{ Tier 3 } \\
\hline Variable & Description & $\mathbf{N}$ & $\mathbf{N}$ & $\mathbf{N}$ & $\mathbf{N}$ & \% \\
\hline Gender & Male & 3 & $60.0 \%$ & 9 & $100.0 \%$ & 8 & $72.7 \%$ \\
& Female & 2 & $40.0 \%$ & & & 3 & $27.3 \%$ \\
\hline
\end{tabular}




\begin{tabular}{|c|c|c|c|c|c|c|c|}
\hline \multirow[t]{4}{*}{ Age } & $31-40$ years & 1 & $20.0 \%$ & 1 & $11.1 \%$ & 3 & $27.3 \%$ \\
\hline & $41-50$ years & 4 & $80.0 \%$ & 2 & $22.2 \%$ & 5 & $45.5 \%$ \\
\hline & $51-60$ years & & & 3 & $33.3 \%$ & 3 & $27.3 \%$ \\
\hline & $61-65$ years & & & 3 & $33.3 \%$ & & \\
\hline \multirow{5}{*}{$\begin{array}{l}\text { Academic } \\
\text { qualification }\end{array}$} & Diploma & 0 & $0.0 \%$ & 0 & $0.0 \%$ & 0 & $0.0 \%$ \\
\hline & Bachelor's degree & 1 & $20.0 \%$ & 2 & $22.2 \%$ & 0 & $0.0 \%$ \\
\hline & Master's degree & 4 & $80.0 \%$ & 5 & $55.6 \%$ & 9 & $81.8 \%$ \\
\hline & Doctorate (PHD) & 0 & $0.0 \%$ & 1 & $11.1 \%$ & 2 & $18.2 \%$ \\
\hline & Professional & 0 & $0.0 \%$ & 1 & $11.1 \%$ & 0 & $0.0 \%$ \\
\hline \multirow[t]{3}{*}{ Job Level } & Chairperson & 2 & $40.0 \%$ & 2 & $22.2 \%$ & 4 & $36.4 \%$ \\
\hline & Chief executive officer CEO & 2 & $40.0 \%$ & 5 & $55.6 \%$ & 5 & $45.5 \%$ \\
\hline & $\begin{array}{l}\text { Deputy chief executive officer } \\
\text { DCEO }\end{array}$ & 1 & $20.0 \%$ & 2 & $22.2 \%$ & 2 & $18.2 \%$ \\
\hline \multirow{5}{*}{$\begin{array}{l}\text { Years } \\
\text { served in the } \\
\text { organization }\end{array}$} & $1-5$ years & 3 & $60.0 \%$ & 6 & $66.7 \%$ & 7 & $63.6 \%$ \\
\hline & $6-10$ years & 1 & $20.0 \%$ & 2 & $22.2 \%$ & 2 & $18.2 \%$ \\
\hline & $11-15$ years & & & 1 & $11.1 \%$ & & \\
\hline & $16-20$ years & 1 & $20.0 \%$ & & & 2 & $18.2 \%$ \\
\hline & $21+$ years & & & & & & \\
\hline
\end{tabular}

Table 4.3 indicated the summary statistics of demographic information of the respondents by the remuneration tiers. The demographic information included gender, age, job level, experience in the organisation and highest level of education. In terms of gender, the findings indicated the majority of the respondents were males across all the three tier groups. With, Tier 1, Tier 2 and Tier 3 having 60\% (3), $100 \%$ (9) and $72.7 \%$ (8) males respectively. The findings further the majority of the females in the sample were Board Chairpersons (3), with only 2 female executives of which 1 was a deputy or in an acting capacity. indicated that Tier 1 the majority of the female $(89.6 \%)$ were males, while $7(10.4 \%)$ were females. The findings imply that the executive appointments are predominantly held by males. While, Board appointments exercise a level of gender mainstreaming allowing women to hold high level positions in Namibian CPEs.

With regards to the age group of the respondents, Table 4.3 revealed that the majority of the respondents (11) were aged between $41-50$ years old $(44 \%)$. While, the $80 \%$ of Tier 1 CPEs were aged between $41-50$ years (4). In Tier 2 only $22.2 \%$ were in this age group and in Tier 3 it doubles to $45.5 \%$. Yet, $66.7 \%$ of Tier 2 respondents were aged above 50 years and $27.3 \%$ of the Tier 3 CPEs respondents were above 50 years. The findings suggest that Tier 2 companies might have challenging business continuity and succession in the near future due to its 33.3\% of respondents in the 61-65 years category. In addition, the findings on the years of service suggests that two thirds of the executives across all tiers, are serving their first 5-year contract terms with $60.0 \%, 66.7 \%$ and $63.6 \%$ of the respondents reporting 1 to 5 years of service for Tier 1 , Tier 2 and Tier 3 CPEs respectively. 


\subsection{Executives' Understanding of their Compensation Packages}

This section covers data collected from the answers to the part B of the questionnaire that required the respondents to choose a statement that closely aligns with their understanding of compensation packages, as the relate to performance in the commercial public enterprises. Table 4.4 presents the findings.

Table 4.4 Executives' Understanding of their Compensation Packages $(\mathrm{N}=25)$

\begin{tabular}{|c|c|c|c|c|}
\hline Code & Variable & Values & $\mathbf{N}$ & $\%$ \\
\hline Secb_2.1 & $\begin{array}{l}\text { Statement best fits your } \\
\text { understanding of compensation } \\
\text { package }\end{array}$ & $\begin{array}{l}\text { Sum of direct benefits and indirect benefits they } \\
\text { receive } \\
\text { The combination of salary and fringe benefits } \\
\text { received from employer } \\
\text { Total payment and benefits receive for doing their job }\end{array}$ & $\begin{array}{l}5 \\
14\end{array}$ & $\begin{array}{l}24.0 \% \\
20.0 \% \\
56.0 \%\end{array}$ \\
\hline Secb_2.2a & $\begin{array}{l}\text { What do you think should be the } \\
\text { main purpose of the } \\
\text { compensation package for } \\
\text { executives }\end{array}$ & $\begin{array}{l}\text { Must attract executive with the skills, experience and } \\
\text { behavioural profile } \\
\text { Must be sufficient to retain these individuals so they } \\
\text { do not leave } \\
\text { Must motivate them to perform in a manner } \\
\text { consistent with the strategy }\end{array}$ & 19 & $\begin{array}{l}24.0 \% \\
0.0 \% \\
76.0 \%\end{array}$ \\
\hline Secb_2.2b & $\begin{array}{l}\text { Do you think better } \\
\text { compensation package is needed }\end{array}$ & No & $\begin{array}{c}5 \\
20\end{array}$ & $\begin{array}{l}20.0 \% \\
80.0 \%\end{array}$ \\
\hline Secb_2.3 & $\begin{array}{l}\text { What is your expectation for a } \\
\text { better compensation package }\end{array}$ & $\begin{array}{l}\text { Fair and transparency to motivate to perform } \\
\text { Fair and transparency linked to performance level } \\
\text { Fair and transparency according to what is agreed in } \\
\text { terms }\end{array}$ & $\begin{array}{c}4 \\
16\end{array}$ & $\begin{array}{l}16.0 \% \\
64.0 \% \\
20.0 \%\end{array}$ \\
\hline
\end{tabular}

From the above table 4.4 there is an indication of respondent having expectation of not leaving, because they are not thinking that the compensation is used to retain them this is explained by their responses on sec_2.2a, on which $0 \%$ of respondents said that they think compensation is not be sufficient to retain these individuals so they do not leave.

\subsection{Executives' Understanding of Performance in the Commercial Public Enterprises}

This section covers data collected from the answers to the part $\mathrm{C}$ of the questionnaire that required the respondents to choose a statement that closely aligns with their understanding of executive's performance in the commercial public enterprises. Table 4.5 presents the findings.

Table 4.5: Executives' Understanding of Performance in their Organisation ( $N=25)$

\begin{tabular}{|c|l|l|c|r|}
\hline Code & Statement & Values & N & \% \\
\hline Secc_3.1 & $\begin{array}{l}\text { Do you have executive performance } \\
\text { policy in your organisation }\end{array}$ & No & 6 & $24.0 \%$ \\
& Yes & 18 & $72.0 \%$ \\
& Not aware & 1 & $4.0 \%$ \\
\hline Secc_3.3a & Is there a relationship between & No & 10 & $40.0 \%$
\end{tabular}




\begin{tabular}{|c|c|c|c|c|}
\hline & $\begin{array}{l}\text { executive compensation package and } \\
\text { performance policy }\end{array}$ & Yes & 15 & $60.0 \%$ \\
\hline Secc_3.4a & $\begin{array}{l}\text { Benefits of executive compensation } \\
\text { package - means of ensuring org is } \\
\text { prepared to attract executives with } \\
\text { better skills }\end{array}$ & $\begin{array}{l}\text { Strongly agree } \\
\text { Agree } \\
\text { Undecided } \\
\text { Disagree } \\
\text { Strongly disagree }\end{array}$ & $\begin{array}{l}10 \\
11 \\
2 \\
1 \\
1\end{array}$ & $\begin{array}{r}40.0 \% \\
44.0 \% \\
8.0 \% \\
4.0 \% \\
4.0 \%\end{array}$ \\
\hline Secc_3.4b & $\begin{array}{l}\text { Benefits of executive compensation } \\
\text { package - continuous supply of } \\
\text { qualified motivated people who } \\
\text { elevate company }\end{array}$ & $\begin{array}{l}\text { Strongly agree } \\
\text { Agree } \\
\text { Undecided } \\
\text { Disagree } \\
\text { Strongly disagree }\end{array}$ & $\begin{array}{l}12 \\
8 \\
2 \\
1 \\
2\end{array}$ & $\begin{array}{r}48.0 \% \\
32.0 \% \\
8.0 \% \\
4.0 \% \\
8.0 \%\end{array}$ \\
\hline Secc_3.4d & $\begin{array}{l}\text { Benefits of executive compensation } \\
\text { package - a way of commitment to } \\
\text { customer satisfaction through } \\
\text { motivation executive }\end{array}$ & $\begin{array}{l}\text { Strongly agree } \\
\text { Agree } \\
\text { Undecided } \\
\text { Disagree } \\
\text { Strongly disagree }\end{array}$ & $\begin{array}{l}5 \\
10 \\
6 \\
1 \\
3\end{array}$ & $\begin{array}{r}20.0 \% \\
40.0 \% \\
24.0 \% \\
4.0 \% \\
12.0 \%\end{array}$ \\
\hline Secc_3.4c & $\begin{array}{l}\text { Benefits of executive compensation } \\
\text { package - a way of achieving your } \\
\text { organisations vision and human } \\
\text { resource }\end{array}$ & $\begin{array}{l}\text { Strongly agree } \\
\text { Agree } \\
\text { Undecided } \\
\text { Disagree } \\
\text { Strongly disagree }\end{array}$ & $\begin{array}{l}6 \\
8 \\
7 \\
2 \\
2\end{array}$ & $\begin{array}{r}24.0 \% \\
32.0 \% \\
28.0 \% \\
8.0 \% \\
8.0 \%\end{array}$ \\
\hline
\end{tabular}

\subsection{Data Pre-processing and Validation}

This section presents the data pre-processing and validation of the combined data from the documentary analysis and the questionnaire survey. The data were first collated into one SPSS data file using the company's variable, as the matching key. This resulted in 35 item variables which were then analysed using the Cronbach's Alpha if item is deleted option in IBM SPSS version 26 to screen for variables, they gave improved scale reliability. The Cronbach's alpha improved from a negative value to a good reliability value of 0.707 from 16 item variables presented in Table 4.7 .

Table 4.7: Cronbach's Alpha Reliability Test Results

\begin{tabular}{|l|l|r|r|r|}
\hline \multicolumn{1}{|c|}{ Code } & \multicolumn{1}{|c|}{ Description } & Mean & $\begin{array}{c}\text { Std. } \\
\text { Dev. }\end{array}$ & $\begin{array}{c}\text { Cronbach's } \\
\text { Alpha if Item } \\
\text { Deleted }\end{array}$ \\
\hline Compensation & Remuneration tiers & 2.24 & 0.78 & 0.687 \\
\hline secA_1.2 & Age & 3.28 & 0.94 & 0.709 \\
\hline
\end{tabular}




\begin{tabular}{|c|c|c|c|c|}
\hline secA_1.3 & Academic qualification & 3.08 & 0.64 & 0.692 \\
\hline secB_2.1 & Statement best fits your understanding of compensation package & 2.32 & 0.85 & 0.692 \\
\hline secB_2.2b & Do you think better compensation package is needed & 1.80 & 0.41 & 0.704 \\
\hline SecB_2.3 & What is your expectation for a better compensation package & 2.04 & 0.61 & 0.713 \\
\hline secC_3.4d & $\begin{array}{l}\text { Benefits of executive compensation package - a way of commitment } \\
\text { to customer satisfaction through motivation executive }\end{array}$ & 2.48 & 1.23 & 0.677 \\
\hline secC_3.4c & $\begin{array}{l}\text { Benefits of executive compensation package - a way of achieving } \\
\text { your organisations vision and human resource }\end{array}$ & 2.44 & 1.19 & 0.718 \\
\hline secD_4.1 & $\begin{array}{l}\text { Have you any successes with compensation package of executives in } \\
\text { your organisation }\end{array}$ & 2.04 & 0.68 & 0.709 \\
\hline secD_4.3 & $\begin{array}{l}\text { Which of the following is often used to determine executive } \\
\text { compensation package }\end{array}$ & 2.80 & 1.00 & 0.707 \\
\hline secD_4.4 & $\begin{array}{l}\text { Have you had any challenges with compensation packages of } \\
\text { executives that hinder performances }\end{array}$ & 1.72 & 0.46 & 0.713 \\
\hline SecF2 & Availability of the current Financial \& Annual Report on website & 2.36 & 1.52 & 0.696 \\
\hline SecF3 & Profitability (reports a profit in the audited financial reports) & 1.36 & 0.49 & 0.673 \\
\hline SecF4 & Tax Paid & 1.48 & 0.71 & 0.667 \\
\hline SecF5 & Paid Dividends to Government & 1.44 & 0.77 & 0.673 \\
\hline SecF6 & Financial support from Government & 2.28 & 0.94 & 0.650 \\
\hline
\end{tabular}

Table 4.7 presents the summary and reliability statistics of the cleaned dataset of 16 item variables, which met the normality requirements for an Exploratory Factor Analysis (EFA). To give statistical meaning to the analysis, factor analysis was undertaken before testing the hypotheses in order to reduce the number of variables and to detect structure in the relationship between variables as well as to discover the underlying constructs that explain the variance (Kline, 2011).

Factor analysis was also performed to confirm the validity and reliability of the constructs of the questionnaire (Pallant, 2013). The distinctive feature of the EFA is that the factors are derived from statistical results and not from theory (Byrne, 2016). The used the Principal Component Analysis (PCA) with Varimax rotation and the Kaiser Normalisation technique, as the best techniques to minimise error and come up with a factor structure of the six factors from the 16-item variables. EFA was used to evaluate each of the 16 items related to the study objectives. Table 4.8 presents the Rotated Component Matrix.

Using the Gaskin \& Lim (2016) AMOS Plugin for importing a Pattern Matrix from IBM SPSS into SPSS AMOS, Table 4.8 was then imported and analysed in IBM SPSS AMOS version 23. The study used Gaskin (2017) model fitness tools and procedures to carry out confirmatory factor analysis and path analysis. However, with a small sample size of 25 , nonnormality increases resulting in the model failing to converge or that result in an improper solution. As such, bootstrapping serves as a resampling procedure by which the original sample is considered to represent the population (Kline, 2011).

\subsection{Conclusions and Recommendations}

The purpose of this paper was to investigate the relationship between compensation packages and the performance of executive officers in commercial Public Enterprises in Namibia.

The paper was guided by the research objective below: 


\subsubsection{Research objectives outlined below:}

- To determine the relationship between compensation package of executives and the performance of Commercial PEs in Namibia.

\subsection{Conclusions}

The analysis of the research findings from the paper indicated that Windhoek Country Club (WCC) had the most exemplary performance in 2019 with up to date audited financial statements (Full AR for FY18/19). As well as, recording a profit for the year and having fully paid their tax obligations, the annual report indicated a significant dividend pay-out of N\$ 6 million in 2019.

Subsequently, the lowest compensation tier (Tier 1) with salary packages of CEOs pegged at mostly N\$1 million included companies like Meatco. However, the sample included AgriBusDev, AMTA and Zambezi Waterfront. In terms of performance, AgriBusDev had the best metrics under this category, with most of its budget supported by central government and its financial information updated to the end of 2017 (Full AR for FY16/17). However, according its annual report of 2017 some of the Green Schemes under its portfolio were loss-making, which affected its profitability. As such, no tax or dividends were paid by the public enterprise in the year 2017.

However, using Hierarchical Cluster Classification in SPSS version 26 to assess and group the public entities based on their performance profiles, the study revealed that there seems to be a relationship between executive compensation and performance in some of the Commercial Public Enterprises. This is reflected below:

- The findings indicate that Windhoek Country Club with a proximity of 2 is closest to NamPower's performance for the year 2019. While, Zambezi Waterfront with a proximity of 33, had the worst performance metrics relative to NamPower in 2019. Additionally, the public enterprises were colorcoded based on their regulated compensation packages. The findings indicated that NamPower CEO's performance deserves to be in Tier 3 (orange). While, the high dissimilarities of TransNamib, Air Namibia and RCC qualifies their compensation packages to be in the Tier 1 ranges due to their poor performances.

- Additionally, Tier 2 entities like WCC and NIP which outperformed some in Tier 3, should have their compensation packages and bonus aligned to those of their counterparts in Tier3 such as NTC, NamWater and MEATCO. In the same light, AgriBusDev's performance for 2019 qualifies a Tier 2 compensation package. With, Epangelo deserving Tier 1 salaries package until it improves its performance to match the NamPower performance. Lastly, AMTA and Zambezi Waterfront had the least favourable performance in the year and their compensation should be the least among the public entities. As a result, the comparison of the survey feedback from AMTA and the answers from NamPower executives will shed light into the complexities of the agency relationships of commercial public entities in Namibia.

The paper concluded that there is a partial relationship between executive compensation and the performance of some commercial public enterprises, in accordance with their Tier Levels. This means there is no direct relationship between 'Executives Performance' and the 'Expectations of their Compensation Packages'. As such, hypothesis testing was done to establish the mediating or conditioning factors that would make the compensation packages of the executives relate to the performance of PEs in Namibia.

\subsection{Recommendations}

Considering the conclusions provided above, the following recommendations are made by the researcher:

Since there is a partial relationship between executive compensation and the performance of some commercial public enterprises, in accordance with their Tier Levels. This means there is no direct relationship between 'Executives Performance' and their 'Expectations of their Compensation Packages'. It 
is recommended that the Government (shareholder) finds the best fit model of executive compensation package in order to induce a positive level of performance.

\section{References}

1. Alagla, S., \& Ali, F. (2012). The role and effect of corporate governance and remuneration consultants on CEO compensation: Empirical evidence from UK companies (Doctoral dissertation, Durham University). Retrieved from http://etheses.dur.ac.uk/3481/

2. Amupadhi, T. (2008). Pay for Performance. Retrieved from http://www.insight.com.na/pay- forperformancel

3. Araujo, J., \& Ribeiro, M. (2017). Thirty Years of Research on Executive Compensation and Return to Shareholders. Journal of Education and Research in Accounting, 11(0), 21-40. Doi:10.17524/repec.v11i0.1622

4. Arif, M. (2019). The Effect of Managerial Competencies, Compensation and Career Planning Toward Employee Performance Through Job Satisfaction at PT. Bank BTPN Tbk Mikro Banking Division (MUR) Pekanbaru Branch. Journal of Management, 17-21.

5. Assenso-Okofo, O., Ali, J., \& Ahmed, K. (2020). The effects of global financial crisis on the relationship between CEO compensation and earnings management. International Journal of Accounting \& Information Management.

6. Bettis, J., Bizjak, J., Coles, J., \& Kalpathy, S. (2018). Performance-vesting provisions in executive compensation. Journal of Accounting and Economics, 66(1), 194 221. Doi: 10.1016/j.jacceco.2018.05.001

7. Bussin, M. (2018). Chief executive officer compensation sensitivity in the South African mining industry. Acta Commercii, 18(1), 1-13.

8. Bussin, M., \& Ncube, M. (2017). Chief Executive Officer and Chief Financial Officer Compensation relationship to company performance in state-owned entities. South African Journal of Economic and Management Sciences, 20(1). Doi: $\quad$ 10.4102/sajems.v20i1.164

9. Bognanno, M. (2010) Executive compensation: A brief review (No. 1002). Department of Economics, Temple University. Retrieved from http: researchgate.net

10. Cable \& Vermeulen, D. (2016). Stop Paying Executives for Performance. Harvard Business Review. Retrieved from https://hbr.org/2016/02/stop-paying-executives-for-performance

11. Carothers, A. (2019). The_impact_of_public_scrutiny_on_ex-ecutive_compensation. Retrieved from https://www.researchgate.net/publication/333864427

12. Callan, S. J., \& Thomas, J. M. (2014). Relating CEO compensation to social performance and financial performance: Does the measure of compensation matter? Corporate Social Responsibility and Environmental Management, 21(4), 202-227.

13. Campbell, W. (2013). Talent Management A four step approach. UK: Institute forEmployment studies

14. Cordeiro, J., He, L., Conyon, M., \& Shaw, T. (2013). Chinese executive compensation: the role of asymmetric performance benchmarks. The European Journal of Finance, 22(4-6), 484 505.Doi: $10.1080 / 1351847 \times .2013 .769892$

15. Cucari, N. (2019). Determinants of say on pay vote: a configurational analysis. International Entrepreneurship and Management Journal, 15(3), $837 \quad$ 856. Doi: $\quad$ 10.1007/s11365 018-0556-X

16. David, M. A. (2011). Social Research: The Basics. New Delhi: Sage publication.

17. Dai, Y. (2014) Research on Influencing Factors of Executive Compensation in China's Monopoly Industries. Open Journal of Business and Management, 2, 210-218. doi: 10.4236/ojbm.2014.23026.

18. Edmans, A. (2016). Performance-Based Pay for Executives Still Works. Harvard Review. Retrieved from https://hbr.org/2016/02/performance-based-pay-for-executives-still- works [Accessed 14 Jan. 2020]. 
19. Elmagrhi, M. H., Ntim, C. G., Wang, Y., Abdou, H. A., \& Zalata, A. M. (2018).Corporate governance disclosure index-executive pay nexus:The moderating effect of governance mechanisms. European Management Review.

20. Gartenberg, C., \& Wulf, J. (2017). Pay harmony? Social comparison and performance compensation in multi-business firms. Organisation Science, 28(1), 39-55.

21. Gao, J. (2019) Literature Review of Executive Compensation Gap and Company Performance. American Journal of Industrial and Business Management, 9, 109 123.https://doi.org/10.4236/ajibm.2019.91009

22. Gaoes, I. (2013, November 18). Disgraced CEOs: Where are they now? The villager Retrieved from https://www.thevillager.com.na/articles/5385/disgraced-ceos where-are-they-now/

23. Gazette, G. (2010, August 12). SOEs Act 2006 No. 4530. State Owned Enterprise Council. Windhoek: The republic of Namibia Government.

24. Greener, S. A. (2018). An Introduction to Business Research Methods. Sheffield: Sheffield Hallam University.

25. Grove, H., \& Clouse, M. (2017). Board compensation committees: CEO pay and market cap performance with implications for investors. Corporate Ownership and Control, 14(3).

Doi: $10.22495 /$ cocv14i3c1art3

26. Hayes, A. (2019). Shareholder. Retrieved from Investopedia: https://www.investopedia.com/terms/s/shareholder.asp

27. Gu, T., \& Venkateswaran, A. (2018). Firm-supplier relations and managerial compensation. Review of Quantitative Finance and Accounting, 51(3), 621-649.

28. Hakweenda, H. (2019). The Presence of Talent Management Practice among the Few Selected State-Owned Enterprises in Namibia. Texila international journal of management, 161-173.

Doi: $\quad$ 10.21522/tijmg.2015.se.19.01.art016

29. Immanuel, S., \& Ngutjinazo, O. (2018). Salary increases for SOE bosses. The Namibian. Retrieved from: http://namibian.com.na

30. Immanuel, S. N. O (2013). Geingob changes SOE categories. The Namibian. Retrieved from: http: //www.namibian.com.na

31. Investopedia. (2019). Factors to Consider When Evaluating Company Management.Retrieved from Investopedia: http: www.investopedia.com

32. Kim, W., Nam, I. C., \& Cuong, T. T. (2010). On the governance of state-owned economic groups in Vietnam. Available at SSRN 1729093.

33. Kakkar, D. (2013). Linking Corporate Governance Reforms and Company Performance: A Review. International Journal in Management and Social Science, 1(2), 36-58.

34. Kirsten, E., \& Du Toit, E. (2018). The relationship between remuneration and financial performance for companies listed on the Johannesburg Stock Exchange. South African Journal of Economic and Management Sciences, 21(1),1-10.

35. Kim, W., Nam, I. C., \& Cuong, T. T. (2010). On the governance of state-owned economic groups in Vietnam. Available at SSRN 1729093.

36. Kubo, K., \& Saito, T. (2004). Determinants and consequences of non-financial incentive for directors: case in Japan

37. Kuepper, J. (2019). Evaluating executive compensation. Retrieved from https://www.investopedia.com/articles/stocks/07/executive_compensation.asp

38. Lozano-Reina, G., \& Sánchez-Marin, G. (2019). Say on pay and executive compensation systematic review and suggestions for developing the field. Human Resource Management Review. Doi: 10.1016/j.hrmr.2019.01.004

39. Lukman, NS, \& Adolphina, A. (2015). Work Environment Analysis, Organizational Commitment, And Compensation of Employee Performance at PT. Bank of North Sulawesi Manado. EMBA Journal: Journal of Economic, Management, Business and Accounting Research, 3 (1). 
40. Mari, M. (2018). Influential Factors on the Bank Employees's Performance. Advances in Social Science, Education and Humanities Research, 66-77.

41. Mazumdar, M. (2017). Top-executives' Compensation: The Role of Corporate Ownership Structure in Japan. The Journal of Asian Finance, Economics and Business, 4(3), 35-43. Doi: 10.13106/jafeb.2017.vol4.no3.35

42. Maloa, F. (2015). Executive compensation: executive attributes and group decision making effects in South African state-owned enterprises. Corporate Ownership and Control, 13(1). Doi: 10.22495/cocv13i1c4p6

43. McClure, B. (2019). A guide to CEO Compensation. Retrieved from https://www.investopedia.com/managing-wealth/guide-ceo-compensation/.

44. Meyer, R. E., Höllerer, M. A., \& Leixnering, S. (2018). A question of value (s): Politicalm connectedness and executive compensation in public sector organisations. International Public Management Journal, 21(3), 477-500.

45. Ministry of Public Enterprise (2016). Hybrid Governance Model for Namibian Public Enterprises. Republic of Namibia: Windhoek

46. Murphy, C. B. (2019). Financial Statements. Retrieved from Investopedia: https://www.investopedia.com/terms/f/financial-statements.asp

47. NamCode. The Corporate Governance Code for Namibia - PDF Free Download. (2020). Retrieved from https://docplayer.net/19415014-Namcode-the-corporate-governance-code-for-namibia.html

48. Ndzi, D. (2014). The Regulation of the Determination of Executive Remuneration (Doctoral dissertation, University of Portsmouth).Retrieved from

https://researchportal.port.ac.uk/portal/files/5948571/The_Regulation_of_the

Determination_of_Executive_Remuneration.

49. Ngatjiheue, C. (2018). Govt spent $\mathrm{N} \$ 12 \mathrm{~b}$ on SOEs last year. The Namibian. Retrieved from: http://namibian.com.na

50. Nguyen, D.L (2017) the Application of Talent Management Theories to the Prevention of "Brain Drain" in China. Metropolia of Applied University: Helsinki

51. Nirenberg, J. (2018). A Multifaceted View of CEO Compensation and Performance: A Case Study. Journal of Social Change, 10(1).

52. Observer, W. (2016). Honeymoon over for SOES. Windhoek Observer. Retrievedfrom http://www.observer.com

53. Obermann, J., \& Velte, P. (2018). Determinants and consequences of executive compensation related shareholder activism and say-on-pay votes: A literature review and research agenda. Journal of Accounting Literature, 40, 116-151.Doi:10.1016/j.acclit.2018.02.001

54. Omoregie, O., \& Kelikume, I. (2017). Executive Compensation and Banking Sector Performance: Evidence from Nigeria. The Journal of Developing Areas, 51(2),1-15. Doi: 10.1353/jda.2017.0027

55. Onuorah, A. N. (2019). Compensation Management and Employee Performance in Nigeria. International Journal of Academic Research in Business and Social Sciences, 384398.

56. Paletta, A., \& Alimehmeti, G. (2016). SOX Disclosure and the Effect of Internal Controls on Executive Compensation. Journal of Accounting, Auditing \& $\quad$ Finance, 33(2), 277-295. Doi: $10.1177 / 0148558 \times 16630445$

57. Pearl Meyer. (2019). Pearl Meyer on Point: Looking ahead of executive pay practices. New York, USA. Retrieved from https://www.pearlmeyer.com > executive-pay practices 2019survey-preview

58. Pogach, J. (2018). Short-termism of executive compensation. Journal of Economic Behaviour and Organization, 148, 150-170. https://doi.org/10.1016/j.jebo.2018.02.014

59. Raithatha, M., \& Komera, S. (2016). Executive compensation and firm performance: Evidence from Indian firms. IIMB Management Review, 28(3), 160-169. Doi: 10.1016/j.iimb.2016.07.002

60. Ramachandran, N., (2018) Relevance of Executive Compensation and Corporate Performance: Indian Automobile Industry. Retrieved from: https://www.researchgate.net/publication/326263753 
61. Reddy, K., Abiddin, S. and You, L. (2015),"Does corporate governance matter in determining CEO compensation in the publicly listed companies in New Zealand? An empirical investigation", Managerial Finance, Vol. 41 No. 3, pp. 301-327. https://doi.org/10.1108/MF-09-2013-0253

62. Saunders, M. L., Lewis, P., \&Thornhill, A. (2016). Research Methods for Business Students.7/e Edinburgh gate: Pearson.

63. Schofield-Georgeson, E. (2018). Regulating executive salaries and reducing pay disparities: Is pay disclosure the answer? Journal of Australian Political Economy.

64. Shaw, P. A. (2012). CEO pay-performance sensitivity in South African financial services companies (Doctoral dissertation, University of Pretoria).

65. Shihepo, T. (2014). Govt fails to rein in CEOs earning above salary cap. The villager.

66. Retrieved from: www.the villager.com.na. Retrieved: on 07/01/2020.

67. Stahl, G. (2012). Global talent management: How Leading Multinationals Build and Sustain Their Talent Pipeline. Fontainebleau: INSEAD.

68. Tarus, E. K. (2014). The relationship between executive compensation and financial performance of insurance companies in Kenya (Doctoral dissertation, Egerton University).

69. Takatsu, s. (1984). Organisational equilibrium under uncertainty. Kybernetes, 13(2), $\quad 87 \quad 92$. Doi: $10.1108 /$ eb005678

70. The Patriot. (2017). Namibia's love for acting CEOs. The Patriot: Balanced and Fair. $\quad$ Retrieved from https://thepatriot.com.na/index.php/2017/03/24/namibias-love-for- acting-CEOs/

71. The Patriot. (2017) Salary War turns dirty. The Patriot: Balanced and Fair. Retrieved from https://thepatriot.com.na/index.php/2017/03/18/salary-war-turns-dirty/

72. Ujah, N. U., \& Okafor, C. E. (2019). The effect of a golden parachute on managed earnings. Managerial Finance.

73. Ünal, 1., \& Aybars, A. (2018). Executive compensation and firm performance: evidencefrom an emerging country. Financial Araştırmalar Ve Çalışmalar Dergisi, $231242 . \quad$ Doi: 10.14784/marufacd.502127

74. Usman, M., Akhter, W., \& Akhtar, A. (2015). Role of board and firm performance in determination of CEO compensation: Evidence from Islamic Republic of Pakistan. Pakistan Journal of Commerce and Social Sciences (PJCSS), 9(2), 641-657.

75. Weidlich, B. E. (2010). SOE bosses may earn up to N\$2, 28 million. The Namibian Retrievedfrom https://www.namibian.com.na/67549/archive-read/SOEbosses may-earn-up-to-N\$228million

76. Yarram, S. R., \& Rice, J. (2017). Executive compensation among Australian mining and non- mining firms: Risk taking, long and short-term incentives. Economic Modelling, 64, 211-220.

77. Yahya, F., \& Ghazali, Z. (2017). Effectiveness of board governance and dividend policy as alignment mechanisms to firm performance and CEO compensation. Cogent Business \& Management, 4(1). doi: 10.1080/23311975.2017.1398124

78. Oyerogba, E. O., Riro, G. K., \& Memba, F. S. (2016). The perceived relationship between executive compensation package and profitability of listed companies in Nigeria.

79. Zouari, Z., Lakhal, F., \& Nekhili, M. (2012). Do CEO's characteristics affect earnings management? Evidence from France. Evidence from France (June 11, 2012). 